\title{
AGNOSTIČKI POGLED NA 30 GODINA TRANZICIJE
}

\section{AN AGNOSTIC VIEW OF 30 YEARS OF TRANSITION}

SAŽETAK: Trideseta godišnjica pada Berlinskog zida samo po sebi nameće temu retrospektive tranzicijskog procesa. Povrh toga 30 godina empirijskih podataka o putu u tržište nudi jedinstvenu istraživačku priliku za propitivanje čitavog skupa teorija koje su oblikovale način razmišljanja nosioca ekonomske politike i javne rasprave tijekom cijeloga procesa. Cilj istraživanja je prvenstveno pokrenuti raspravu o čimbenicima relativnog zaostajanja (rasta), ali isto tako i o empirijskoj utemeljenosti hipoteza, odnosno "vjerovanja" koja su oblikovala rasprave o ekonomskom (ne)uspjehu hrvatskog gospodarstva tijekom tranzicije. Analizirani su podaci za preko 40 makroekonomskih indikatora u 31 tranzicijskoj zemlji u razdoblju nakon 1989. godine. Uključeni su podaci i za Daleki istok, a među potencijalnim čimbenicima rasta analizirani su klasični čimbenici rasta i čitav niz makroekonomskih pokazatelja iz sfere fiskalne, monetarne i međunarodne ekonomije. Rezultati istraživanja ukazuju kako možemo uočiti samo manji broj tranzicijskih specifičnosti u odnosu na klasične čimbenike rasta. Međutim, u analizi strukture čimbenika rasta jako teško pronalazimo empirijska uporišta za uobičajena teoretska predviđanja.

KLJUČNE RIJEČI: Tranzicija, konvergencija, ekonomski rast, deindustrijalizacija, faktori rasta

ABSTRACT: The thirtieth anniversary of the fall of the Berlin Wall calls for a retrospective analysis of the transition process. Moreover, thirty-years-worth of empirical data on the transition to market economy provides a unique research opportunity to evaluate a whole group of theories that, throughout the process, influenced the mindset of the protagonists of economic policy and public debate. The aim of this study is primarily to initiate a discussion about the factors of relative delay (in growth), as well as to test the empirical basis of hypotheses, i.e. „beliefs“", which determined the discussions about the economic success (or lack of it) of the Croatian economy in the transition period. We analysed the data for over 40 macroeconomic indicators in 31 transition countries for the period after 1989. The data for the Far East have also been included. The potential factors of growth involved

Prof. dr. sc. Josip Tica, Ekonomski fakultet Zagreb, Sveučilište u Zagrebu, Trg J. F. Kennedy 6, 10000 Zagreb, e-mail: jtica@efzg.hr 
in our analysis included a range of macroeconomic indicators from the fiscal, monetary and international economic spheres. Our research results reveal that, in respect of classical growth factors, only a small number of transition-specific features can be identified. However, our analysis of growth factors' structure showed that it is only with great difficulty that the usual theoretical predictions can be grounded in empirical data.

KEY WORDS: transition, convergence, economic growth, deindustrialisation, growth factors

\section{UVOD}

Cilj ovoga rada je empirijski provjeriti relativnu uspješnost tranzicijskih zemalja u kontekstu ekonomskog rasta i ekonomskih teorija koje mogu objasniti razlike u dinamici među zemljama. Tijekom 2019. godine obilježiti ćemo tridesetu godišnjicu pada Berlinskog zida i protesta na Tienanmanskom trgu. Događaja koji su simbolički i suštinski odredili smjer ekonomskih reformi koje su uslijedile u gospodarstvima koja su do tada opisivana planskim, odnosno samoupravnim ekonomskim sustavima. Reforme bazirane na Washingtonskom konsenzusu, kao i reforme Deng Xiaopinga koje su pokrenule prijelaz u socijalizam sa kineskim karakteristikama odredile su ekonomsku sudbinu skoro dvije milijarde ljudi u prostoru od istočne Njemačke do Vietnama i korejskog poluotoka.

Trideseta godišnjica pokretanja navedenih reformi izvrstan je povod za retrospektivno sagledavanje podataka o ekonomskoj izvedbi promatrane, tranzicijske grupe zemalja sa ciljem prosudbe ekonomskih teorija u okviru kojih su ekonomista tada, ali i danas prosuđivali kvalitetu ekonomskih politika. Opseg rada je preuzak za provjeravanje svih mogućih pokazatelja, teorijski okvira i općenito paradigmi u sagledavanju tranzicijskog procesa, ali i tržišta i ekonomije općenito. Stoga, usmjeravamo pažnju prvenstveno na rezultate ekonomskog procesa u smislu BDP-a per capita, odnosno stope rasta životnog standarda općenito.

Odabir predmeta promatranja je uvijek normativan u svojoj biti, stoga je možda važno istaknuti kako je BDP kao pokazatelj manjkav sam po sebi iz najmanje dva razloga. Prvo, ne uzima u obzir distribuciju dohotka između različitih dohodovnih decila/kvartila stanovništva. Više je nego moguće da bi poredak zemalja po stopi rasta nacionalnog dohotka $10 \%$ najsiromašniji stanovnika unutar svake zemlje bio bitno različit od stope rasta prosječnog BDP-a per capita za sve stanovnike. Drugo, BDP kao i nacionalni dohodak ne mjeri kvalitativne aspekte razvoja, od očekivanog trajanja života, do pristupa obrazovanju, zdravstvenom sustavu, kvalitete okoliša itd. Sukladno tome, sam odabir BDP-a per capita za početak ovoga istraživanja u prvom slučaju treba promatrati kao početni korak uvjetovan dostupnošću podataka za cijelo promatrano razdoblje, a u manjoj mjeri normativnim odabirom prioriteta ekonomske politike.

\section{REZULTATI TRANZICIJSKOG PROCESA}

Tranzicija je simbolički počela padom Berlinskog zida 9. studenog 1989. g., ali formalno u smislu ekonomskih reformi, kao početak za istočnu Europu možemo označiti 1.1.1990. godine kada Poljska, Mađarska, tadašnja Češkoslovačka i Jugoslavija započinju 
program stabilizacije. ${ }^{1}$ Početna faza tranzicije je s izuzetkom Poljske u sve četiri zemlje obilježena tranzicijskom depresijom i snažnim padom BDP-a, da bi nakon nekoliko godina pojavile pozitivne stope rasta u restrukturiranom djelu gospodarstva. Sličan scenarij sa zakašnjenjem se dogodio kasnije i u ostalim tranzicijskim zemljama Europe uključujući i Rusiju. Navedeni početak tranzicijskih reformi se ne odnosi na Kinu. Prijelaz u socijalizam sa kineskim karakteristikama započeo je krajem sedamdesetih godina dvadesetog stoljeća. Program je izvedena na način da se forsiraju tržišni elementi u poljoprivredi, industrijskim zonama i izvozno orijentiranoj razmjeni sa inozemstvom u kontekstu posebnih ekonomskih, industrijskih i poljoprivrednih zona bez reforme političkog sustava.

Najtočniji prikaz rasta tijekom tranzicijskog razdoblja trebao bi dakle uključiti 1990. godinu kao početnu godinu kako bi se unutar prosječne stope rasta obuhvatilo razdoblje snažnog početnog pada BDP-a na početku tranzicijskih reformi u Europi i bivšem SSSR-u, odnosno izbjegavanje početnog pada u Poljskoj, Kini i Vijetnamu. Navedeno je učinjeno u ekonometrijskom dijelu rada, a u grafičkoj analizi smo za početnu godinu za izračun prosječne stope rasta odabrali 1995 iz najmanje dva razloga. Prvo, željeli smo izbjeći dio tranzicijskog razdoblja koje pokriva Domovinski rat kako bi promatrali Hrvatsko zaostajanje tijekom mirnodopskog razdoblja. Drugo, željeli smo se ograničiti samo na podatke svjetske banke iz razloga što su koncipirani na jedinstvenoj metodologiji i uključuju BDP u PPP dolarima za usporedbu razine razvijenosti i realne stope rasta BDP-a u domaćoj valuti za usporedbu rasta tranzicijskih ekonomija. Sukladno, tome zbog nedostatka dostupnih podataka po jedinstvenoj metodologiji, za neke zemlje podaci prije 1995. ili 1994. nisu bili dostupni, te su korišteni podaci iz Penn World Table 9.1 (Feenstra, Inklaar i Timmer, 2015).

Analiziramo li BDP per capita tranzicijskih zemalja u 1995. i 2017. g. razvidno je kako su sve zemlje znatno unaprijedile svoj životni standard. Dok je npr. 1995. godine Bugarska sa 5000 PPP USD bila u sredini ljestvice po životnom standardu, u 2017. najnerazvijenija tranzicijska zemlja Tajikistan se polako počeo približavati navedenom stupnju razvoja (3195 PPP USD). Tijekom tog istog razdoblja, Češka i Slovenija su više nego udvostručile svoj životni standard, a Kina gotovo učetverostručila. U velikoj većini zemalja koji su prošle kroz tranzicijski depresiju, rast iz razdoblja nakon 1995. godine nadoknadio je početni pad BDP-a.

Neke zemlje (Češka i Slovenija) zadržale su svoje mjesto kao najrazvijenije tranzicijske zemlje tijekom cijelog promatranog razdoblja. Neke druge zemlje su snažno napredovale. Npr. Litva je sa osmog mjesta došla na treće mjesto po razvijenosti među tranzicijskim zemljama, a Estonija sa sedmog na četvrto mjesto. Kina je krenula s donjeg dijela ljestvice i tijekom navedenog razdoblja sustigla je Srbiju po PPP BDP-u per capita i pozicionirala se čvrsto u sredini ljestvice. Naravno, postoje zemlje koje su loše prošle u tranziciji. Hrvatska je pala s petog na jedanaesto mjesto po razvijenosti, puno bolji razvojni rezultat nije ostvarila niti Mađarska koja je s trećeg mjesta 1995. završila na osmom mjestu. Makedonija je sličan primjer relativnog razvojnog neuspjeha tijekom kojeg je unatoč rastu standarda zaostajala te pala sa sredine ljestvice u donji dio po razvijenosti.

Reformski program Ante Markovića u tadašnjoj Jugoslaviji je započeo denominacijom dinara 1:10000 i stabilizacijom tadašnjeg dinara na tečaju 7:1 prema njemačkoj marci. 


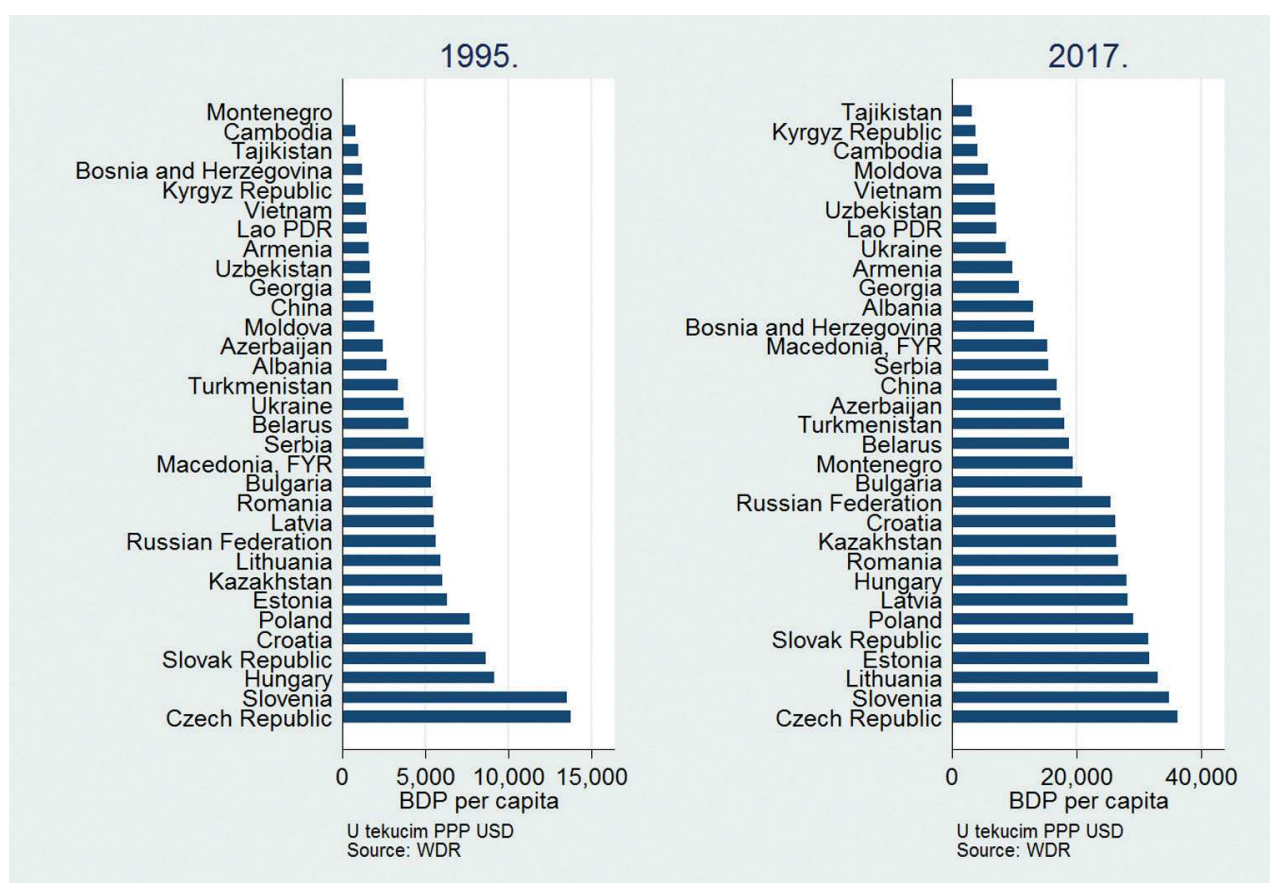

Grafikon 1: Razina životnog standarda u tranzicijskim zemljama 1995. i 2017. godine mjerena PPP BDP-om po stanovniku

Izvor: WDR (2019)

Osim podataka o razinama BDP-a per capita mjerenim po paritetu kupovne moći, interesantno je analizirati i stope rasta BDP-a per capita koje su zabilježile tranzicijske zemlje tijekom navedenog razdoblja. Grafikon 1 prikazuje stope rasta od 1990. do 2017. (lijevo) i stope rasta od 1995. do 2017. (desno). Najbrže rastuće gospodarstvo u oba razdoblja je bila Kina, najsporije rastuće gospodarstvo je Ukrajina. Ukrajina, Moldova i Tađikistan imaju negativnu prosječnu stopu rasta od 1990. Zanimljivo je kako većina zemalja, kada se uključi prva polovina devedesetih, ima manje prosječne stope rasta. Kako zemlje istočne Europe, tako i Kina. Izuzeci se npr. Vijetnam i Laos.

Nakon 1995. najbrže stope rasta zabilježile su Kina, Azerbajđan i Gruzija, ako ne računamo $\mathrm{BiH}$ koja je tijekom sredine devedesetih imala enormno visoke stope rasta tijekom poslijeratne konsolidacije gospodarstva. ${ }^{2}$ Iako su i dalje pri vrhu po BDP-u per capita, Slovenija, Mađarska, Češka i Hrvatska su pri dnu po zabilježenim stopama rasta tijekom ovoga razdoblja.

Spomenute zemlje se uklapaju u stiliziranu činjenicu kako zemlje s niskom osnovicom rastu brže, ali postoji čitav niz zemalja čija početna razina BDP-a per capita ne korelira negativno sa stopama rasta tijekom tranzicije. Poljska je u sredini ljestvice po stopama rasta, Ukrajina i Crna Gora su na dnu, Litva je sedmo najbrže rastuće gospodarstvo tranzicije s prosječnom stopom rasta od preko 5\%. Estonija i Slovačka su također u sredini poretka uz Poljsku.

Podaci za BiH su uklonjeni zbog nepouzdanosti i stopa rasta koje dosežu i preko $40 \%$ godišnje. 


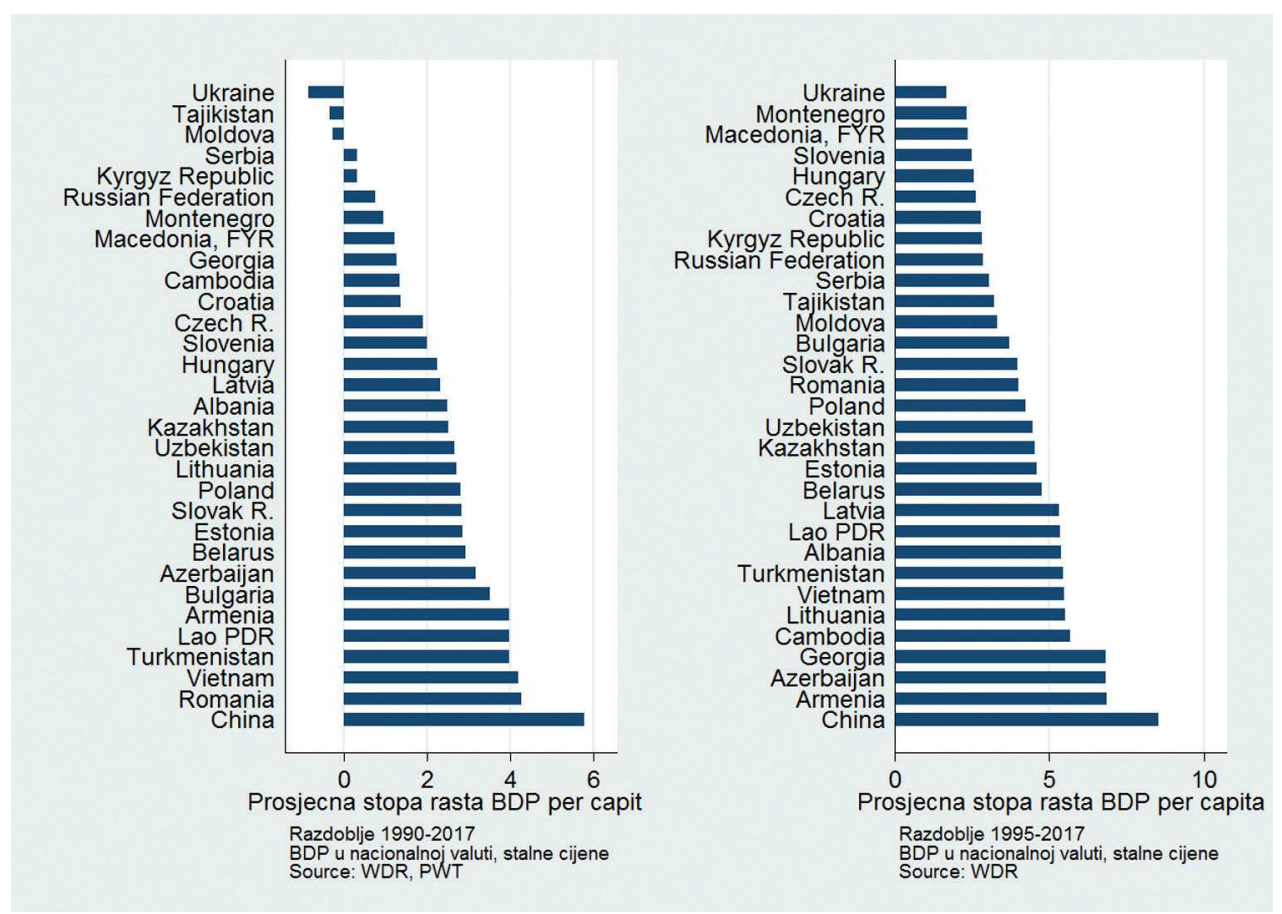

Grafikon 2: Prosječne stope rasta BDP-a per capita između 1990. (lijevo), odnosno 1995. (desno)

i 2017. godine na temelju BDP-a u nacionalnoj valuti

Izvor: WDR (2019) i Feenstra, Inklaar i Timmer (2015)

Očigledno je kako početna razina BDP-a per capita donekle predviđa ekonomski rast tijekom tranzicije, ali nije presudan i dominirajući čimbenik u objašnjavanju razvojnih performansi tranzicijskih gospodarstava. Sukladno tome, analiza je nastavljena kroz empirijski pregled čimbenika rasta iz teorije rasta i provjeru korelacije između čimbenika rasta i stope rasta tranzicijskih zemalja.

\section{KLASIČNI FAKTORI RASTA - SOLOW I TRANZICIJSKE ZEMLJE}

Objašnjavanje dugoročnih performansi rasta ekonomisti najčešće rade u kontekstu Solowljeve teorije rasta $(1956,1994)$. Prema teoriji, razlike u dohotku među zemljama u dugom roku (dužem od desetljeća u svakom slučaju) možemo objasniti razlikama u količini realnih investicija, rastu populacije i ukupnoj faktorskoj produktivnosti (Solowljevom rezidualu), odnosno efikasnosti kojom se koristi rad i kapital u proizvodnji. Prema osnovnim implikacijama teorije, veću razinu BDP-a per capita bi u dugom roku trebale imati zemlje koje u prosjeku imaju više stope investicija i zemlje koje imaju nižu stopu rasta populacije. Veće investicije bi prema teoriji trebale rezultirati većom akumulacijom fizičkog kapitala, a rezultat bi trebao biti sve veći dohodak, a niža stopa populacije bi trebala značiti da se 
dohodak dijeli (per capita) sa brojem stanovnika koji raste sporije od dohotka. Isto tako, prema osnovnom modelu, siromašnije zemlje bi zbog opadajućih prinosa na kapital trebale rasti brže od bogatih zemalja što bi trebalo rezultirati konvergencijom životnog standarda između bogatih i siromašnih zemalja.

Iako u početku samo teorijski koncept, Solowljeva teorija rasta je doživjela empirijsku potvrdu tijekom osamdesetih nakon što je doživjela empirijsku potvrdu na podacima prikupljenim unutar Penn World Table projekta (Feenstra, Inklaar i Timmer, 2015). Rast popularnosti teorije rezultirao je i čitavim nizom istraživanja koji je i proširio sami teorijski koncept. Durlauf, Johnson i Temple (2004, p.74.) u preglednom radu ističu kako je u literaturi o uzrocima dugoročnog rasta moguće pronaći 43 zasebne teorije koje proširuju osnovni Solowljev model.

Grafikon 3 prikazuje korelaciju između prosječne stope rasta od 1995. do 2017. u tranzicijskim zemljama i početne razine BDP-a per capita u 1995. godini. Očigledno je iz prikazanih podataka kako postoji relativno razvidna negativna korelacija između početne razine BDP-a per capita i stopa rasta koje su potom uslijedile. Ne radi se o dominantnom procesu, ali je razvidno da su dvije najrazvijenije zemlje u 1995. imale nakon toga znatno manje stope rasta od prosjeka, te da je najbrže rastuća Kina u 1995. imala skoro najmanju razinu BDP-per capita. Naravno, kao i u svakoj teoriji, postoje zemlje koje bitno odstupaju od konvergencije kao što su Tajikistan ili Kirgistan sa niskim stopama rasta i niskom razinom razvijenosti u 1995. godini.

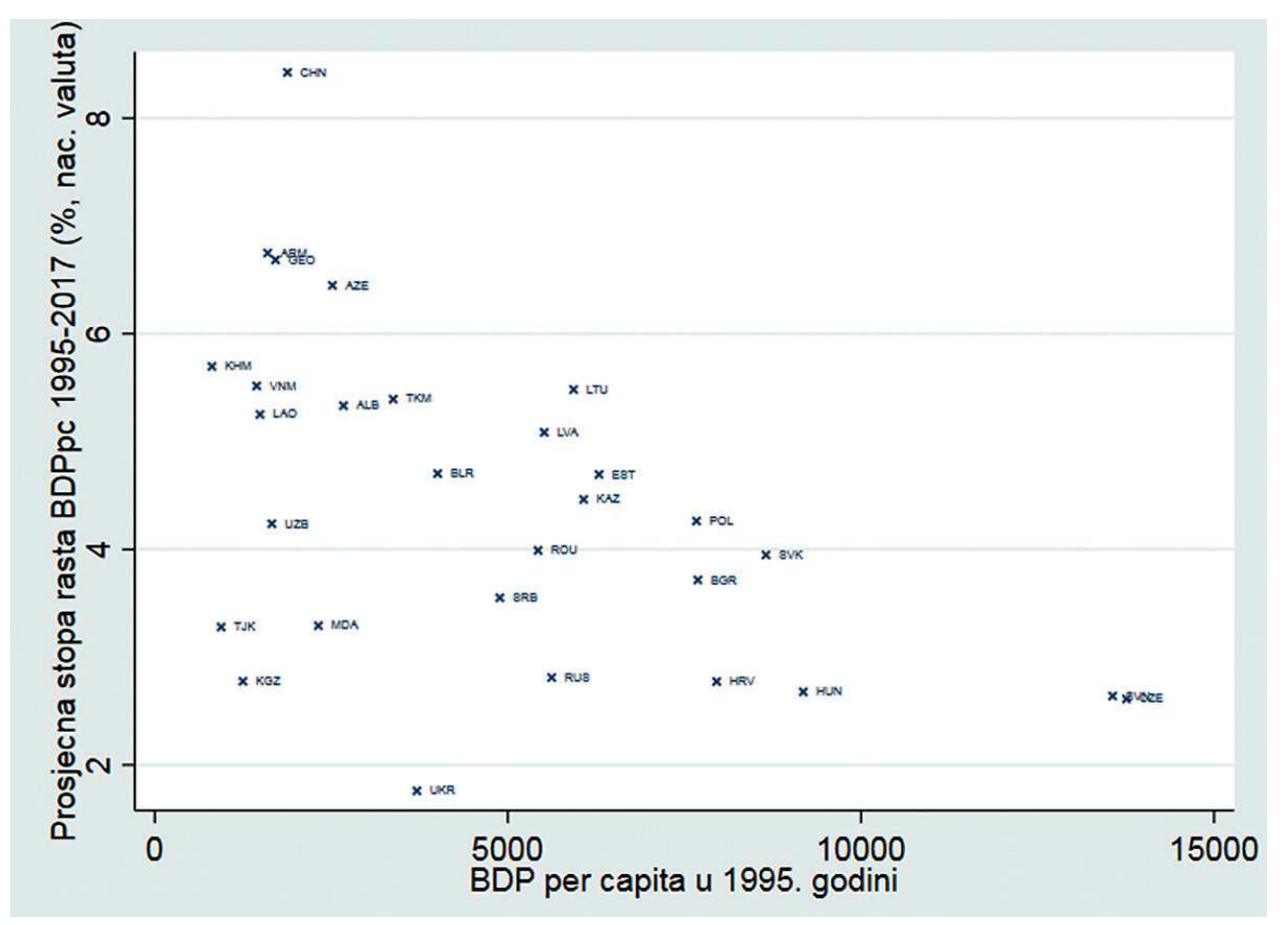

Grafikon 3: Utjecaj početne razine razvijenosti na stope rasta BDP-a per capita tijekom tranzicije

Izvor: WDI (2019) 
Grafikon 4 prikazuje korelaciju između prosječne stope rasta (95-17) i udjela investicija u BDP-u per capita. Većina opservacija ukazuje na pozitivnu vezu između investicija i ekonomskog rasta. Više je nego razvidno kako u razdoblju od promatranih dvadesetak godina upravo investicije mogu objasniti dobar dio devijacija u prosječnim stopama rasta među zemljama. Politika poticanja investicija, ali isto tako i politika privlačenja investicija je očigledno, kako Solow model i predviđa na ovom stupnju razvoja, jedna od ključnih poluga rasta.

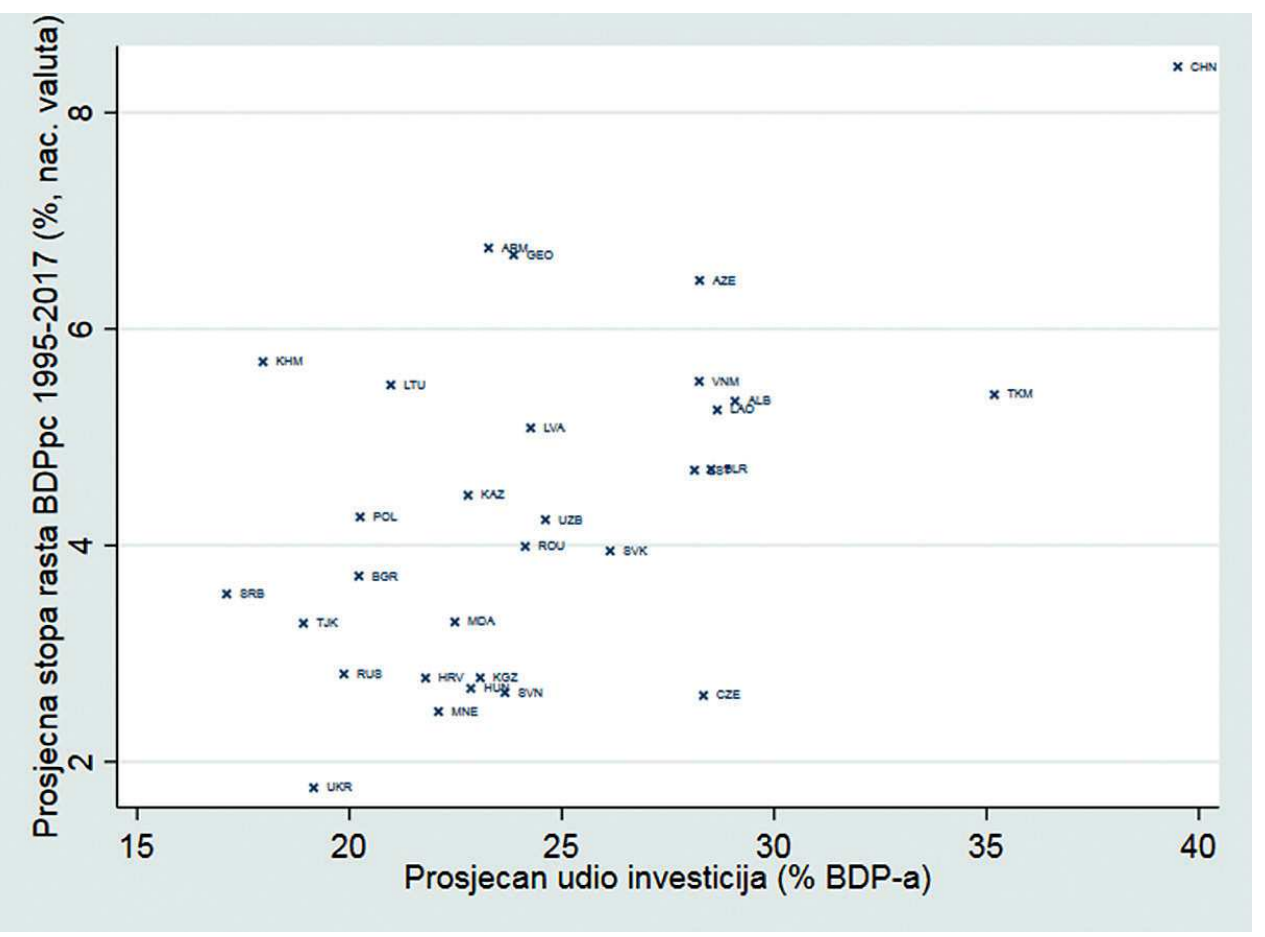

Grafikon 4: Prosječan udio investicija u BDP-u i stopa rasta BDP-a per capita

Izvor: WDI (2019)

Grafikon 5 prikazuje korelaciju između stope rasta populacije i stope rasta BDP-a per capita. Kako je BDP per capita u biti BDP podijeljen brojem stanovnika, manja stopa rasta nazivnika bi trebala biti korelirana s većom stopom rasta razlomka. Podaci u globalu izgledaju nekorelirano, ali ako pogledamo zasebno dvije skupine zemlja, europske tranzicijske zemlje (uključujući Rusiju) i azijske tranzicijske zemlje, razvidna je izrazito jaka negativna korelacija unutar obje skupine zemalja. U azijskoj grupaciji, Kina je s politikom jednog djeteta zabilježila najnižu stopu rasta populacije (uz Kazakhstan), i najvišu stopu rasta BDP-a per capita, a Tađikistan je na suprotnom spektru s rastom populacije od $2 \%$ i stopom rasta BDP-a per capita od otprilike 3\%. Unutar europske grupacije zemalja, Gruzija ima najveći pad stanovnika i najvišu stopu rasta uz Armeniju, a u suprotnom ekstremu je Makedonija s niskom prosječnom stopom rasta i pozitivnim rastom populacije. 


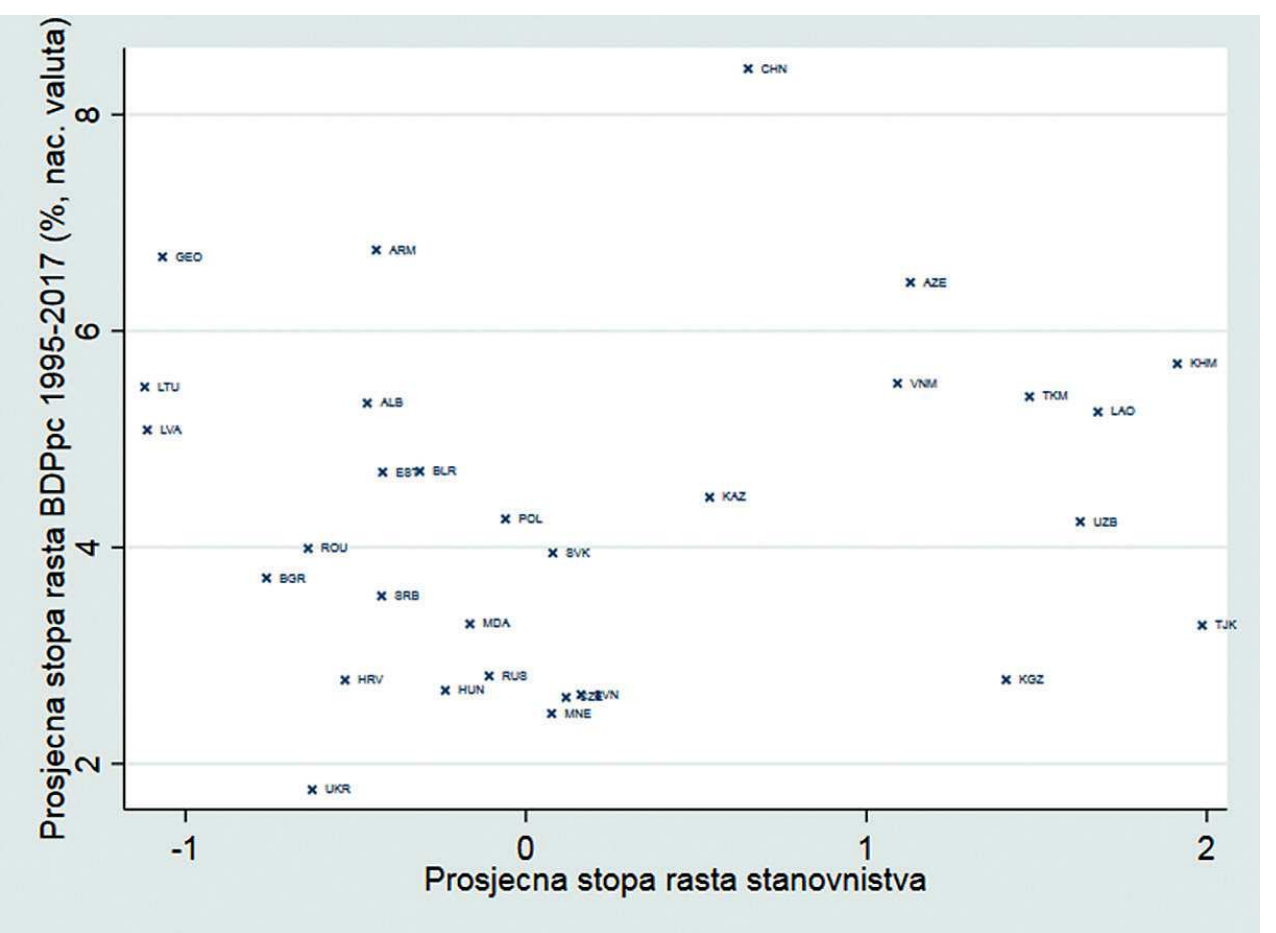

Grafikon 5: Prosječna stopa rasta populacije i stopa rasta BDP-a per capita

Izvor: WDI (2019)

Kao što je već kazano, Durlauf, Johnson i Temple (2004, p.74.) su identificirali 74 teoretska proširenja Solowljeve teorije. Jedno od najpoznatijih teoretskih proširenja, a svakako i najpoznatiji empirijski rad koji testira teoriju rast i konvergenciju je istraživanje koje su proveli Mankiew, Romer i Weil (1992). Njihovo istraživanje ažurira teoriju sa količinom ljudskog kapitala i u empirijskoj potvrdi, koristeći podatke za postotak stanovništva sa sekundarnim školovanjem, empirijski dokazuju kako Solowljev model proširen ljudskim kapitalom može objasniti znatno veći postotak varijacije (80\%) BDP-a per capita među zemljama. Prema teoriji, ulaganje u obrazovanje nije proračunski trošak, nego investicija u produktivnost radne snage i kao takav povećava proizvodne kapacitete gospodarstva.

Grafikon 6 prikazuje korelaciju između stope rasta BDP-a per capita i stope rasta ljudskog kapitala. Ovaj podatak tradicionalno ukazuje na visoku stopu korelacije između rasta i akumulacije ljudskog kapitala. Na ovome grafikonu je većina opservacija grupirana oko zamišljenog rastućeg pravca. Armenija je rasla brže nego što implicira akumulacija ljudskog kapitala, a Vijetnam je akumulirao ljudski kapital (ulagao u obrazovanje) znatno više nego što to implicira njegova stopa rasta. Ostale zemlje (za koje su dostupni podaci) su grupirane oko pozitivnog nagiba na grafikonu. 


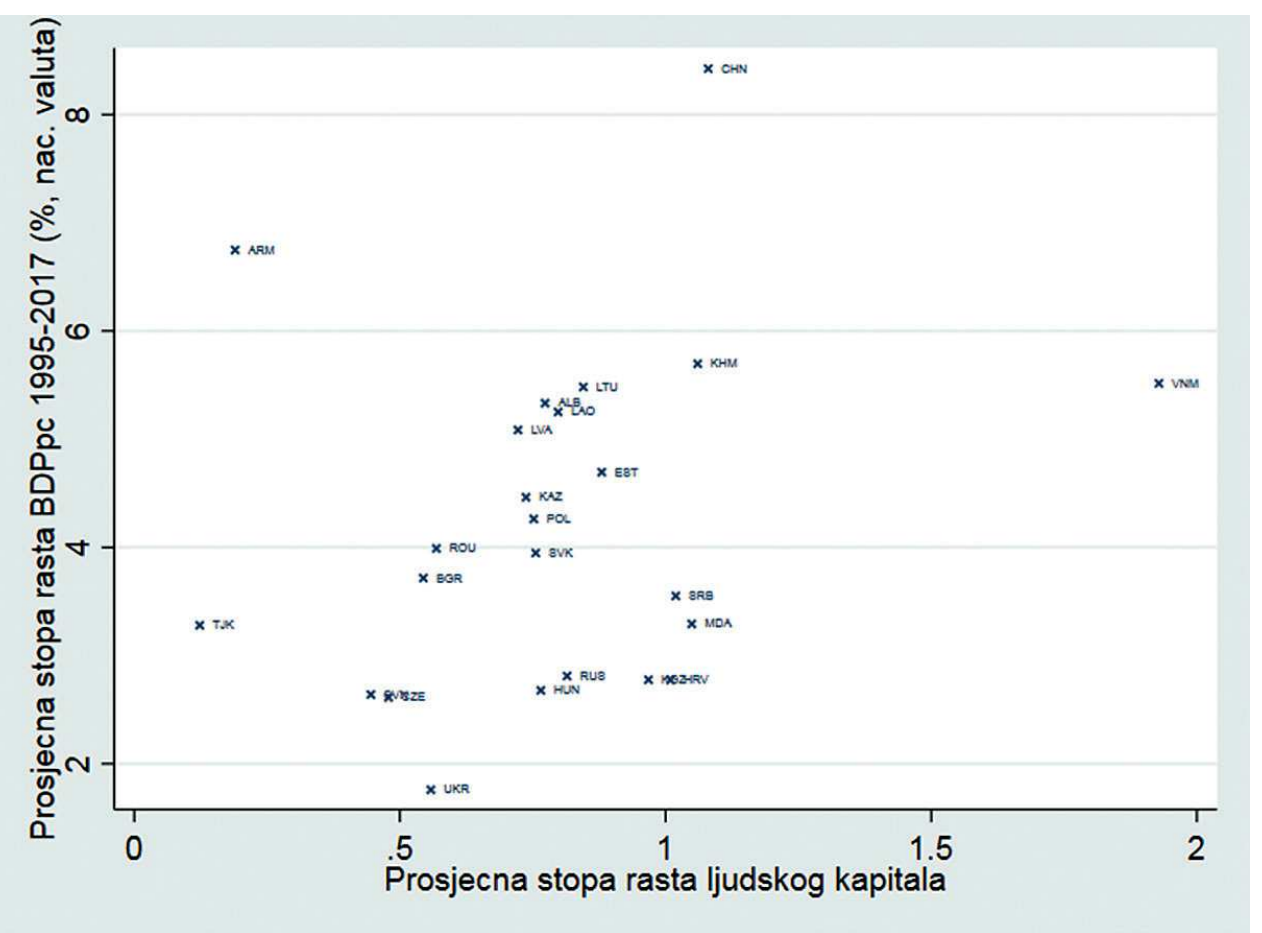

Grafikon 6: Prosječna stopa rasta ljudskog kapitala i stopa rasta BDP-a per capita

Izvor: WDI (2019) i Feenstra, Inklaar i Timmer (2015)

Demografska kretanja koja su slijedila nakon objave Solowljeve teorije rezultirala su i određenim korekcijama u osnovnim pretpostavkama modela. Solow je u modelu pretpostavio konstantnu stopu nezaposlenosti i konstantnu stopu participacije radne snage, kao i konstantnu stopu dobne ovisnosti stanovništva. Demografska kretanja u 21. stoljeću, poglavito starenje stanovništva rezultirala su popriličnom zabrinutošću ekonomista po pitanju irelevantnosti ovih pretpostavki. Osim starenja poseban interes izazvala je činjenica kako BDP po zaposlenom i BDP po stanovniku empirijski gledano nisu sinonimi (Blomstrom, et al. 1996). ${ }^{3}$

Čak i u dugim vremenskim razdobljima, procesi starenja stanovništva ili tržišta rada koja ne funkcioniraju kvalitetno, mogu stvoriti divergenciju između pokazatelja BDP-a po zaposlenom i BDP-a per capita. Sukladno tome, imajući u vidu demografske specifičnosti, važno je provjeriti i da li promjene u stopi zaposlenosti mogu objasniti promjene u stopi rasta BDP-a per capita. Pad broja radno (aktivnog) sposobnog stanovništva zbog demografskog starenja ili prijevremenog umirovljenja može vrlo lako smanjiti radnu snage u uvjetima kada ukupan broj stanovnika ostaje isti i na taj način djelovati na pad BDP-a po stanovniku.

Blomstrom, et al. (1996) su prvi uključili stopu participacije kako bi kontrolirali procjenu za razlike između stope rasta populacije i stope rasta radne snage. 
Grafikon 7 prikazuje odnos između stope rasta udjela zaposlenih u odrasloj populaciji (stariji od 15) i stope rasta BDP-a per capita tijekom 1995-2017. Kao što hipoteza i predviđa, zemlje kojima stopa rasta udjela zaposlenih raste imaju veću stopu rasta BDP-a per capita. Što veći udio populacije sudjeluje u svijetu rada, više se proizvede, pa je i BDP po stanovniku veći.

Na grafikonu se posebno ističu Hrvatska, Ukrajina, Moldavija i Rumunjska kao zemlje u kojima je prosječna stopa rasta stope zaposlenosti bila negativna tijekom razdoblja, a rast nizak. Velika većina zemalja je tijekom tranzicije uspjela povećati stopu rasta zaposlenosti i na taj način doprinijela rastu životnog standarda.

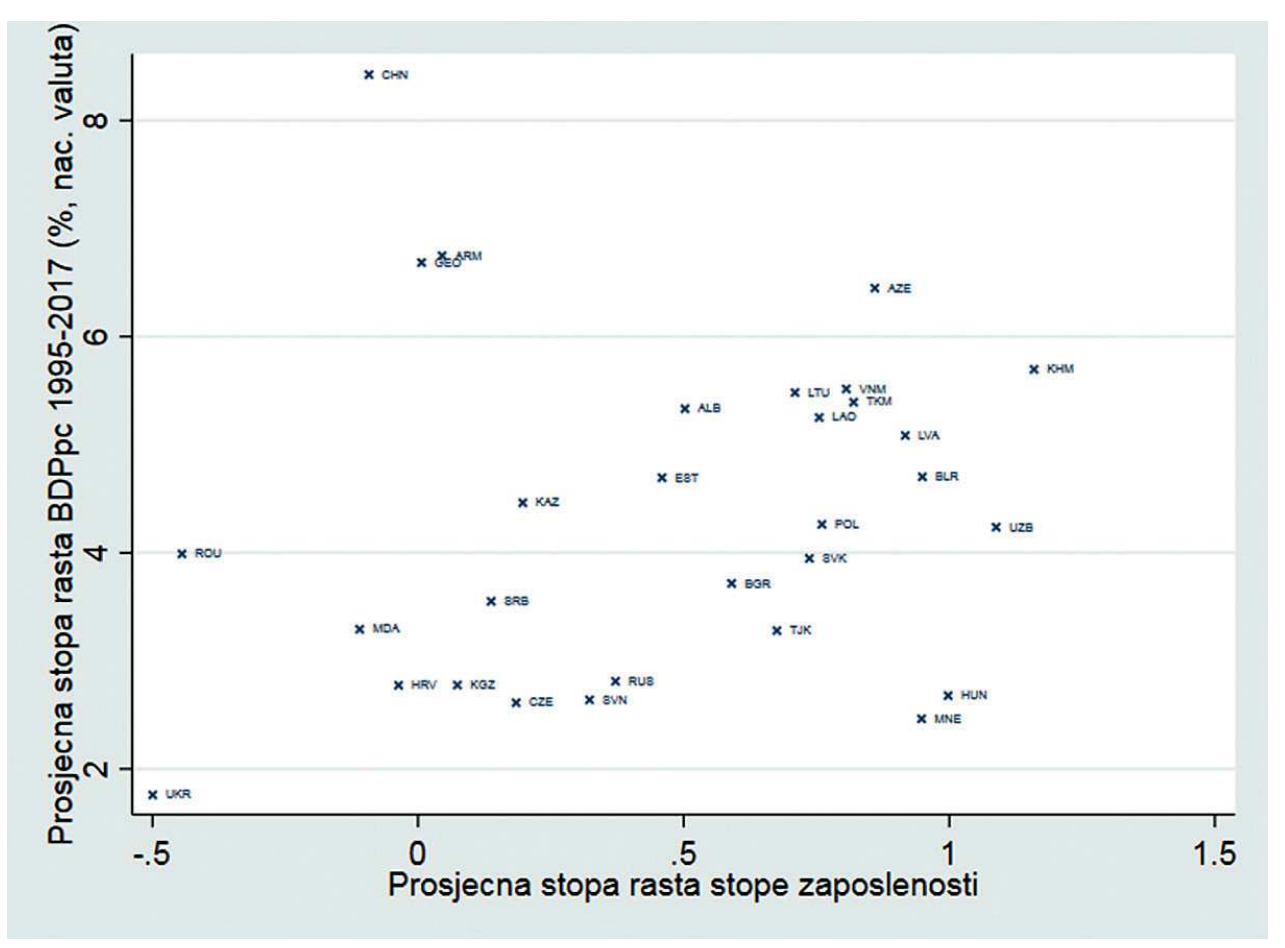

Grafikon 7: Prosječna stopa rasta zaposlenosti i stopa rasta BDP-a per capita

Izvor: WDI (2019)

Iskustvo Azijski tigrova, a kasnije i Kine je ukazalo i na važnost ekonomske (trgovinske) otvorenosti u razmjeni sa svijetom, odnosno važnosti trgovinskih, financijskih i demografskih kretanja na transfer tehnologije i rast efikasnosti gospodarstava (Levine and Renelt 1992; Frankel and Romer 1999).

Međutim, podaci pokazuju na činjenicu kako ne postoji neka lagano uočljiva korelacija između otvorenosti mjerene udjelom zbroja uvoza i izvoza u BDP-u i prosječne stope rasta. Razlog vjerojatno treba tražiti i u različitim veličinama unutarnjeg tržišta različitih zemalja. Udio udjela od skoro 50\% u Kini kao drugoj najvećoj ekonomiji na svijetu ili Latviji teško je usporediv sa udjelom od gotovo $100 \%$ u Latviji. Očigledno je i na grafiko- 
nu kako mnogoljudnija i geografski prostranija gospodarstva imaju manje udjele uvoza i izvoza iako i po tom pitanju postoji iznimke. Vijetnam sa 100 mil. stanovnika ima omjer od gotovo $150 \%$, a Albanija sa 2,8 miliona stanovnika jedva $70 \%$.

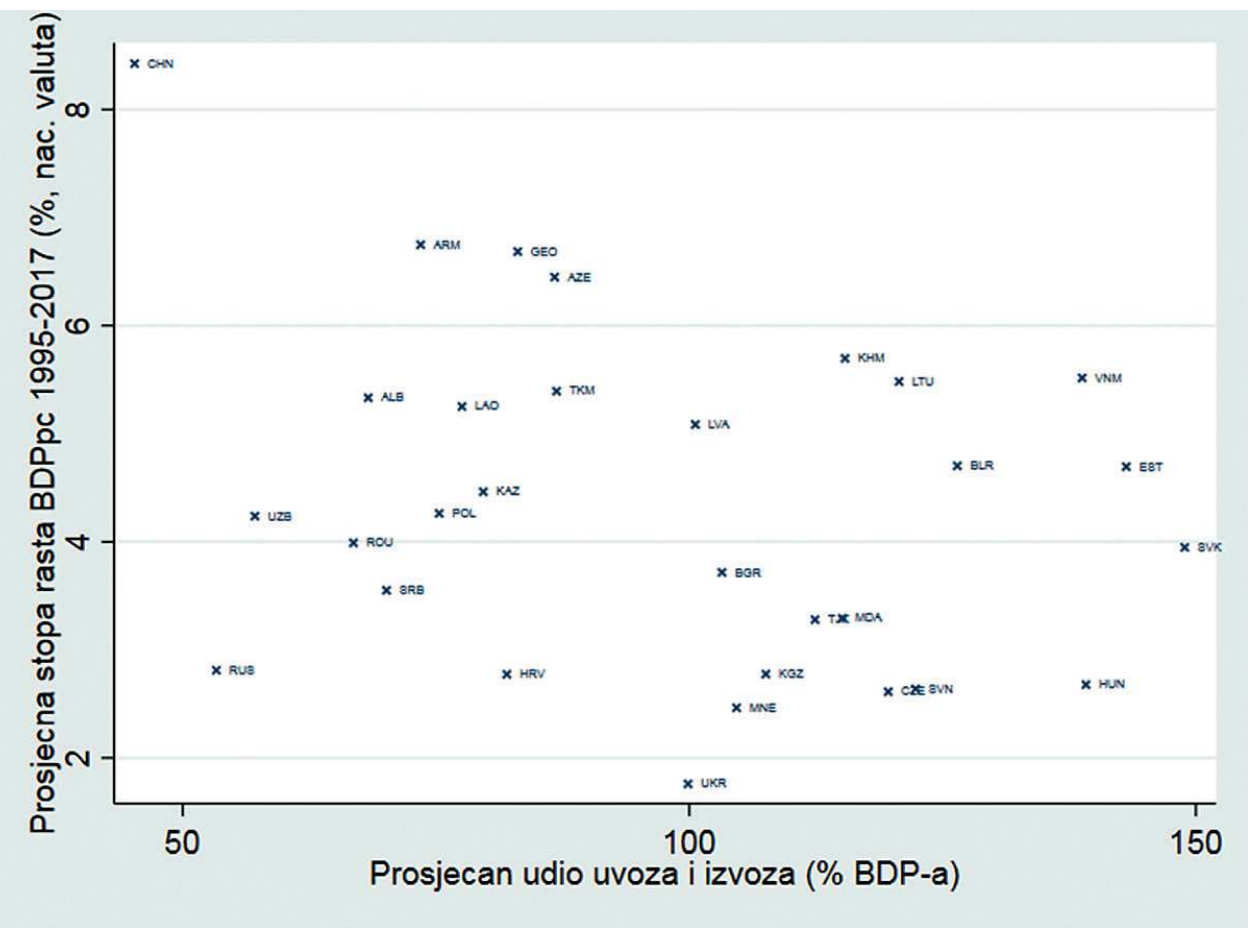

Grafikon 8: Prosječna otvorenost ekonomije i stopa rasta BDP-a per capita

Izvor: WDI (2019)

Tijekom posljednje gospodarske krize 2008. godine veliku pozornost stručne javnosti zaokupilo je i pitanja javnog duga, odnosno udjela javnog duga i njegovog efekta za ekonomski rast zemalja tijekom ekonomskog razvoja (Reinhart i Rogoff 2010). Prema hipotezi, rast javnog duga bi trebao nakon određene razine javnog duga početi djelovati negativno na ekonomski rast. Servisiranje duga bi prema teoriji s njegovim rastom trebalo početi djelovati negativno na akumulaciju čimbenika rasta.

Vodeći se tezom kako ne postoji loš dug, nego samo loše upotrijebljeni dug, umjesto korelacije između udjela duga u BDP-u i stope rasta BDP-a, odlučili smo se koristiti podatke o udjelu kamata na javni dug u BDP-u. Ukupan iznos duga je statistička kategorija, a ono što ima realne reperkusije na funkcioniranje gospodarstva i političku stabilnost zemlje je udio kamata koje se na godišnjoj razini plaćaju vjerovnicima po javnom dugu. ${ }^{4}$ Udio kamata u BDP-u ovisi o najmanje dva čimbenika. Prvi čimbenik je kamatna stopa na javni dug.

Kako država nema biološki vijek trajanja, na javni dug se plaća samo kamata i nema otplate glavnice. Dospjelu glavnicu moguće je refinancirati ili otplatiti tekućim proračunskim viškovima. 
Više je nego moguće da dvije zemlje sa istom razinom javnog duga plaćaju različiti iznos kamate na javni dug zbog različite razine kreditnog boniteta među zemljama. Drugi čimbenik je sama razina javnog duga. Dodatno zaduživanje može biti iskorišteno produktivno i povećati očekivanu stopu rasta BDP-a i smanjiti očekivane deficite ili suprotno može samo povećati očekivane deficite. Sukladno tome, kamata plaćena na javni dug agregira visinu javnog duga i mudrost u njegovu trošenju u jedinstven indikator.

Grafikon 9 prikazuje korelaciju između stope rasta BDP-a per capita i udjela kamate plaćene na javni dug u BDP-u. Negativna korelacija između pokazatelja je više nego jasna. Zemlje sa nižim udjelom kamata plaćenih na javni dug imale su veće stope rasta i obrnuto, zemlje s višim udjelom kamata su imale niže stope rasta.

Ovdje je naravno važno imati na umu činjenicu kako je kauzalnost moguća u oba smjera. Veća stopa rasta će smanjiti premiju rizika za zemlju i samim time smanjiti visinu plaćene kamate na javnih dug. S druge strane, veći iznos kamata na javni dug može istisnuti ostale proračunske stavke iz proračunskih rashoda te na taj način djelovati na smanjenje kapitalnih izdataka ili ulaganja u obrazovanje ili zdravstvo.

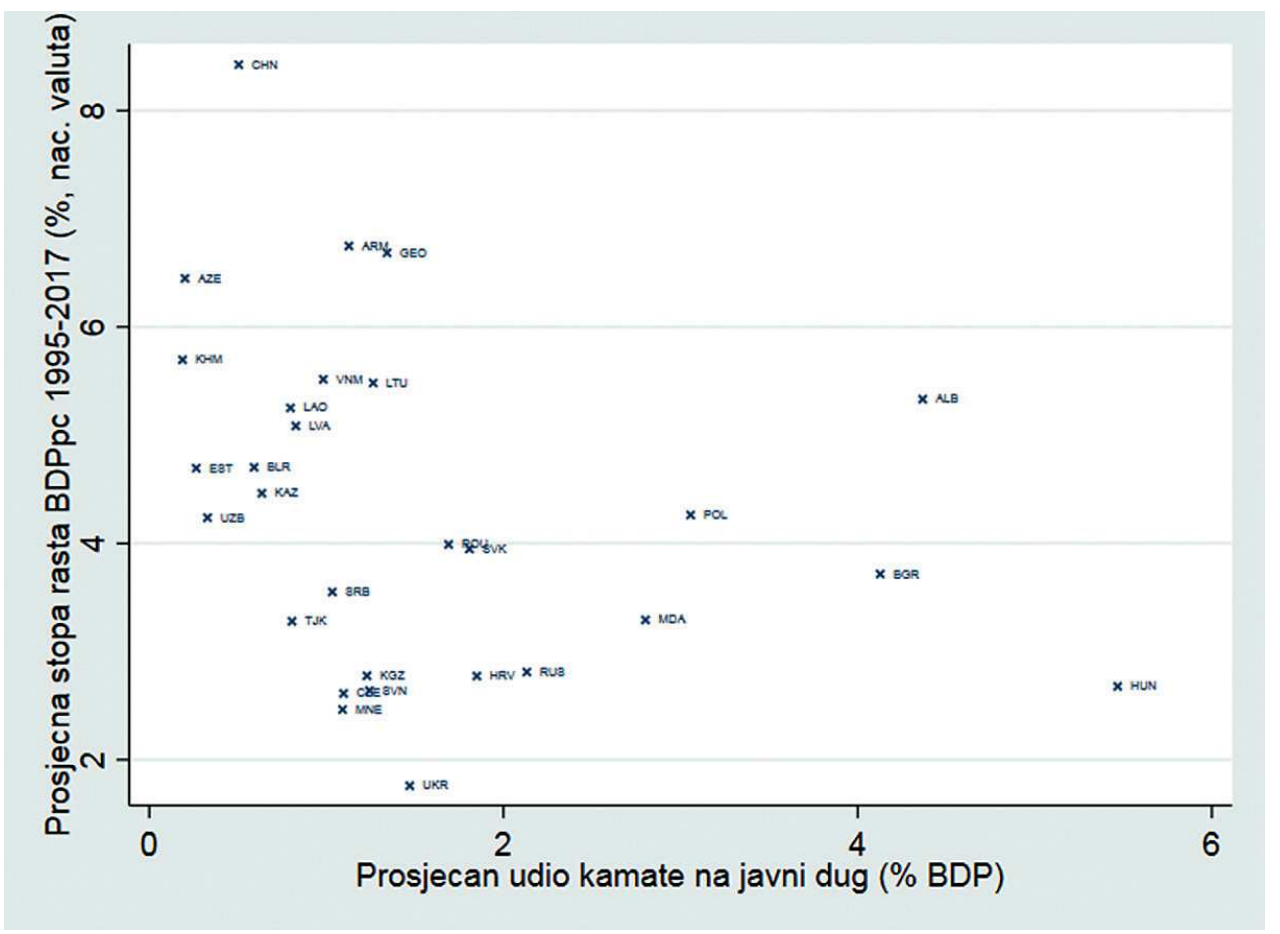

Grafikon 9: Prosječna stopa rasta BDP-a per capita i prosječan udio kamate plaćene na javni dug u BDP-u

Izvor: MMF (2019) i WDI (2019) 
Kada govorimo o monetarnoj politici, Dollar (1992) je prvi analizirao utjecaj distorzija realnog tečaja na dugoročni ekonomski rast, ${ }^{5}$ a Levine and Zervos (1993) su analizirali utjecaj kapitaliziranosti financijskih tržišta kao aproksimaciju razvoja financijskog tržišta na razvoj tranzicijskih zemalja. Romer (1990) je proširio Solow model se endogenom proizvodnjom tehnologije i pokrenuo čitav niz radova o utjecaju broja patenata, ulaganja u R\&D, složenosti proizvoda, tehnološki složenog izvoza na ekonomski rast.

Iako ćemo u regresijskoj analizi koristiti sve navedene varijable, zbog uštede prostora u radu, prikazati ćemo grafikon rasipanja samo za precijenjenost realnog tečaja u odnosu na Harrod Balassa Samuelson trend. ${ }^{6}$ Slovenija i Hrvatska se kao zemlje koje su ušle $\mathrm{u}$ tranziciju na izuzetno visokoj razini cijena, nalaze u donjem desnom dijelu grafikona sa precijenjenim tečajem i niskim stopama rasta u prosjeku. Azerbejđan je na suprotnom dijelu grafikona sa obrnutom kombinacijom, ali negativan međuodnos između navedenih varijabli se ne nameće sam po sebi. Kina je cijelo vrijeme u odnosu na ostale tranzicijske zemlje, a s obzirom na BDP per capita imala precijenjen tečaj (iznad 0\% na horizontalnoj osi), ali je kao što znamo imala najveće stope rasta. Sličan slučaj je i sa Ukrajinom koja je najsporije rasla, a tečaj joj je bio podcijenjen u prosjeku tijekom razdoblja.

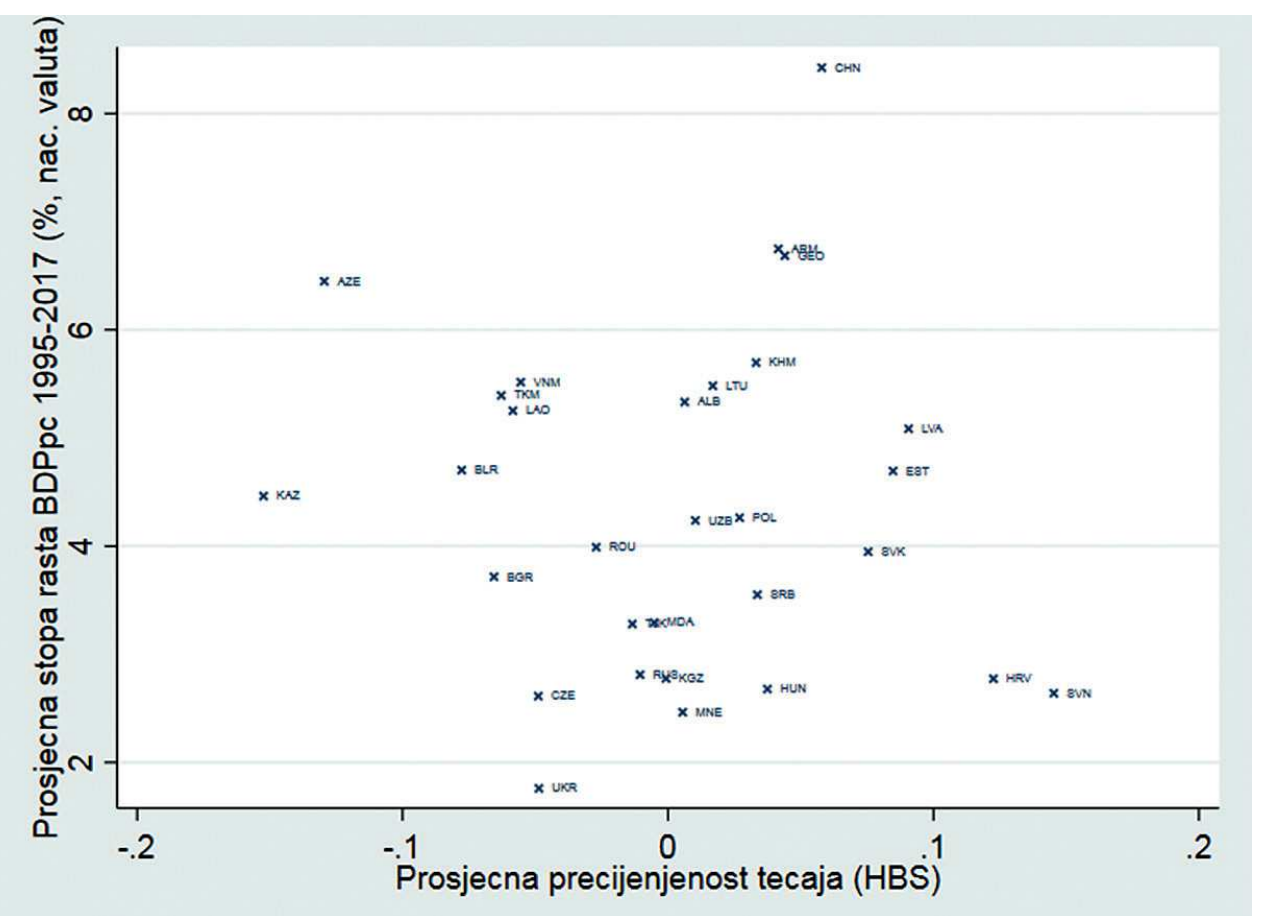

Grafikon 10: Odnos između prosječne precijenjenosti realnog tečaja i prosječne stope rasta BDP-a per capita (1995-2017)

Izvor: WDR (2019)

\footnotetext{
Sala-i-Martin (1997ab i Acemoglu, et al. (2002) su kasnije proširili analizu utjecaja realnog tečaja. Procijenjen je utjecaj BDP-a per capita na PPP indeks te su rezidualni iz panela fisknih efekata korišteni kao mjera precijenjenosti realnog tečaja.
} 


\section{SEKTORSKE PROMJENE GOSPODARSTAVA}

Osim empirijske provjere utjecaja osnovnih čimbenika rasta na stopu rasta u tranzicijskim zemljama, moguće je empirijski provjeriti i teorije vezane uz industrijalizaciju i deindustrijalizaciju te povezanost navedenih procesa sa razinom BDP-a per capita. Jedna od osnovnih teorija vezana uz strukturne promjene gospodarstva je bazirana na teoretskom očekivanju kako će s porastom BDP-a per capita na najnižim stupnjevima razvoja u strukturi gospodarstva dominirati primarni sektor. Nakon toga dominantan postaje sekundarni sektor, odnosno industrijski sektor, da bi u posljednjoj fazi razvoja započeo proces deindustrijalizacije, odnosno sporijeg rasta industrija od ostatka gospodarstva, te posljedično pada udjela industrije u BDP-u (Obadić 2003; Penava, Kovačević i Sekur 2016).

Provjera odnosa razine BDP-a per capita i udjela pojedinih sektora u gospodarstvu može nam pomoći pružiti uvid u poziciju na kojoj se nalaze tranzicijske zemlje trenutno, odnosno gdje su se tranzicijske zemlje nalazile tijekom tranzicijskog procesa.

Grafikon 11 prikazuje udjele dodane vrijednosti prerađivačke industrije (lijevo), prihoda od ekstrakcije prirodnih bogatstava (sredina) i primitke od turizma (desno) u BDP-u u 2016. godini. Zemlje su na vertikalnoj osi poredane prema BDP-u per capita od najnerazvijenije prema najrazvijenijoj (Grafikon 1 prikazuje seriju korištenu za rangiranje). Iz lijevog grafikona je jasno kako udio industrije u BDP-u ne pokazuje nikakvu tendenciju smanjenja kako se krećemo od vrha (najnerazvijenije zemlje) prema dnu (najrazvijenije zemlje).

Najveće udjele industrije u BDP-u imaju Kina i Češka od kojih je prva u sredini ljestvice, a druga najrazvijenija zemlja u uzorku. Udio prerađivačke industrije veći od $20 \%$ BDP-a imaju Češka, Slovenija, Slovačka, Mađarska, Rumunjska, Bjelorusija i Kina. Od 18 najnerazvijeniji zemalja samo Kina ima udio veći od 20\%. Od 9 najrazvijenih zemalja tri baltičke države i Poljska nemaju udio industrije iznad 20\%. Očigledno je ovako površno gledajući kako upravo najuspješnije zemlje tranzicije imaju velike udjele prerađivačke industrije, a ne obrnuto. Navedena empirijska činjenica implicira kako su možda tranzicijske zemlje nedovoljno razvijene da bi se u podacima zabilježio efekt deindustrijalizacije. Barem gledajući ovako u globalu. 




Grafikon 11: Udio prerađivačke industrije, prihoda od renti od nafte i rudnih bogatstava i primici od turizma

Izvor: WDR(2019)

Pogledamo li ulogu renti od ekstrakcije prirodnih resursa (srednji grafikon) izgledno je kako među devet najrazvijenijih zemalja nema niti jednog gospodarstva u kojem su rente od prirodnih resursa (nafta i rudna bogatstva) značajan izvor prihoda u odnosu na BDP. Približno 20\% ili više od renti od prirodnih resursa imaju Kazakstan, Ruska Federacija, Turkmenistan, Azerbejđan, Uzbekistan i Laos. Očigledno je kako niti jedna razvijena zemlja tranzicije ne bazira svoje gospodarstvo na ekstrakciji prirodnih bogatstava. S druge strane među brzo rastućim tranzicijskim zemljama možemo pronaći Azerbejđan, Turkmenistan i Laos (Grafikon 2).

Grafikon 5 na desnoj strani prikazuje udio primitaka od turizma u BDP-u. Dakle, ne radi se o dodanoj vrijednosti turizma, nego samo o udjelu financijskih transakcija vezanih uz turizam koje su ušle u zemlju. U 2016. godini, Crna Gora, Hrvatska i Albanija na jadranskoj obali uz Gruziju i Kambođu su se isticale sa udjelom primitaka od turizma od preko $10 \%$ BDP-a. Iako je turizam kao i rudarstvo sličan zbog baziranosti na prirodnim resursima (jadranska obala ili crnomorska obala) i/ili kulturnim bogatstvima (Kambođa), te ekstrakciji dohotka iz svojevrsnih prirodnih ili kulturnih/povijesnih "resursa", ipak je specifičan u kontekstu uslužnih djelatnosti i bitno različitih potreba za radnom snagom. Unutar skupine zemalja koja ima visok (>10\%) udio primitaka od turizma nema zemalja koje spadaju u skupinu najrazvijenijih tranzicijskih gospodarstava, ali među brzorastućim tranzicijskim zemljama možemo pronaći Gruziju i Kambođu (Grafikon 2). 
Grafikon 12 prikazuje kretanje udjela usluga (lijevo), industrije (sredina) i poljoprivrede (desno) u BDP-u za 11 tranzicijskih zemalja koje su članice Europske Unije. Uz izuzetak Kazakstana i Ruske Federacije radi se u biti o 11 najrazvijenijih tranzicijskih zemalja mjereno BDP-om per capita (Grafikon 1). Iako je razvidno na grafikonu kako je udio poljoprivrede negativno koreliran sa stupnjem razvijenosti, kod usluga i industrije je teško donijeti ikakav zaključak gledajući grafikon rasipanja.

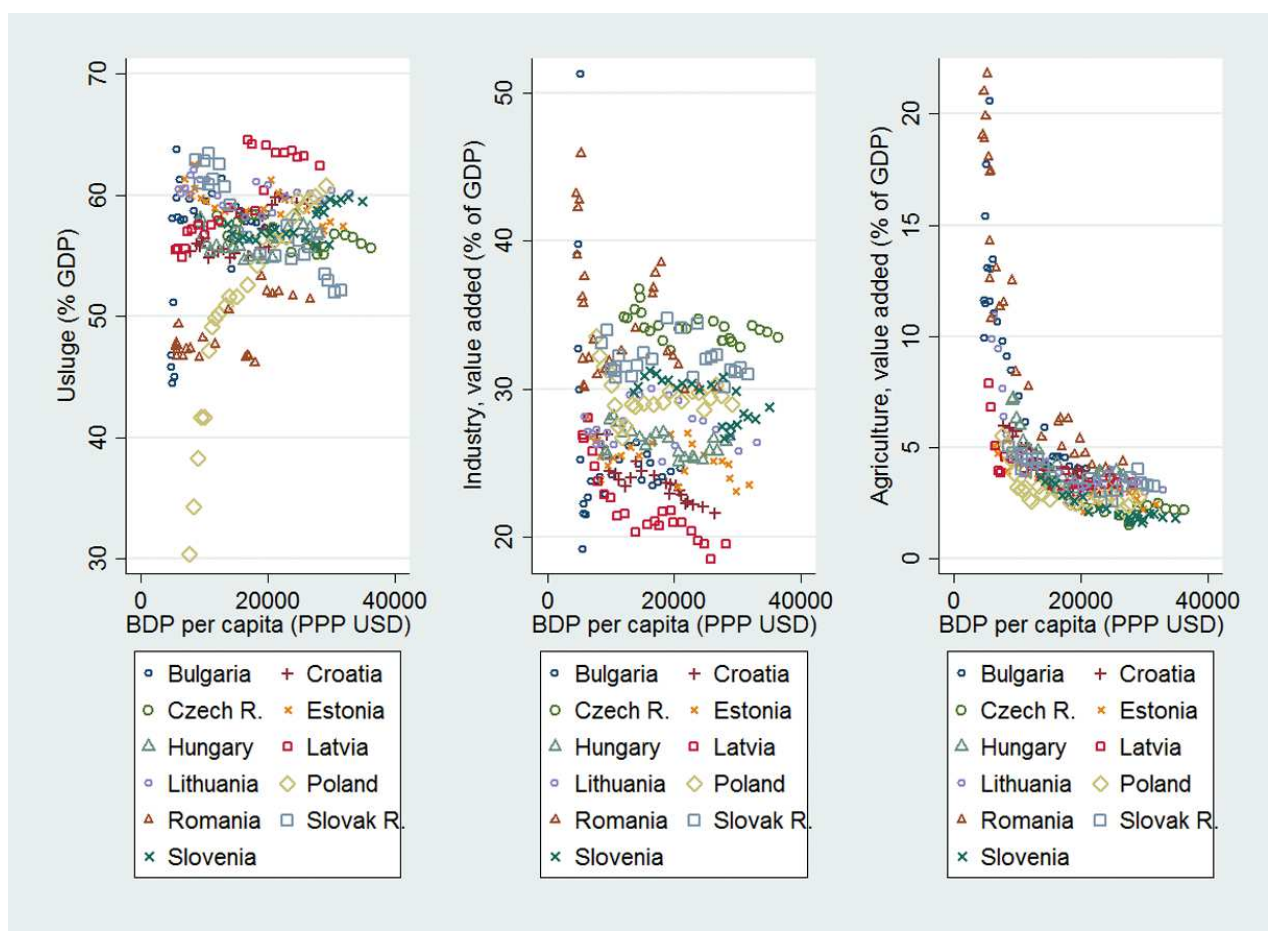

Grafikon 12: Usluge, poljoprivreda i industrija u odnosu na BDP po stanovniku

Izvor: WDR (2019)

Moguće je doduše ustvrditi za neke zemlje da im opada udio industrije sa ekonomskim razvojem (Latvia i Hrvatska) a nekim drugim raste (Slovenija i Poljska), ali gledajući kompletan uzorak novih članica EU nemoguće je na robustan način utvrditi pozitivnu ili negativnu vezu među varijablama.

Analizu je moguće proširiti na odjeljke prerađivačke industrije jer postoje podaci za prerađivačku industriju, odjevnu i tekstilnu industriju, prehrambenu industriju, industriju strojeva i transportne opreme, kemijsku industriju i ostalu industriju. Sektorskom analizom prerađivačke industrije možemo dobiti uvid u utjecaj razvoja na strukturu gospodarstva i pokušati procijeniti situaciju u kojoj se nalazi Hrvatska u odnosu na ostale tranzicijske zemlje.

Grafikon 13 prikazuje udio prerađivačke industrije (lijevo), odjevne i tekstilne industrije (sredina) i prehrambene industrije (desno) u BDP-u. Veza udjela prerađivačke industrije u BDP-u u odnosu na stupanj razvoja prikazuje sličan obrazac ponašanja kao i u slučaju cijele 
industrije (Grafikon 12). U nekim zemljama postoji pozitivna korelacija, a u drugim negativna. Na razini cjelokupnog uzorka međutim nije moguće uočiti neki opći zakon opadajućeg udjela prerađivačke industrije. Međutim kada promatramo udjele odjevne i tekstilne, kao i prehrambene industrije (srednji i desni grafikon), više je nego očita negativna korelacija iako je rasipanje veće nego u slučaju kod udjela poljoprivrede (Grafikon 12). Grafikon 13 je jako koristan za razvoj intuicije jer paralelno imamo dva grafikona (srednji i desni) na kojima se manifestira negativna korelacija u gotovo svim zemljama i na razini cijelog uzroka, dok je u slučaju cjelokupne prerađivačke industrije bila kakva korelacija manje razvidna.

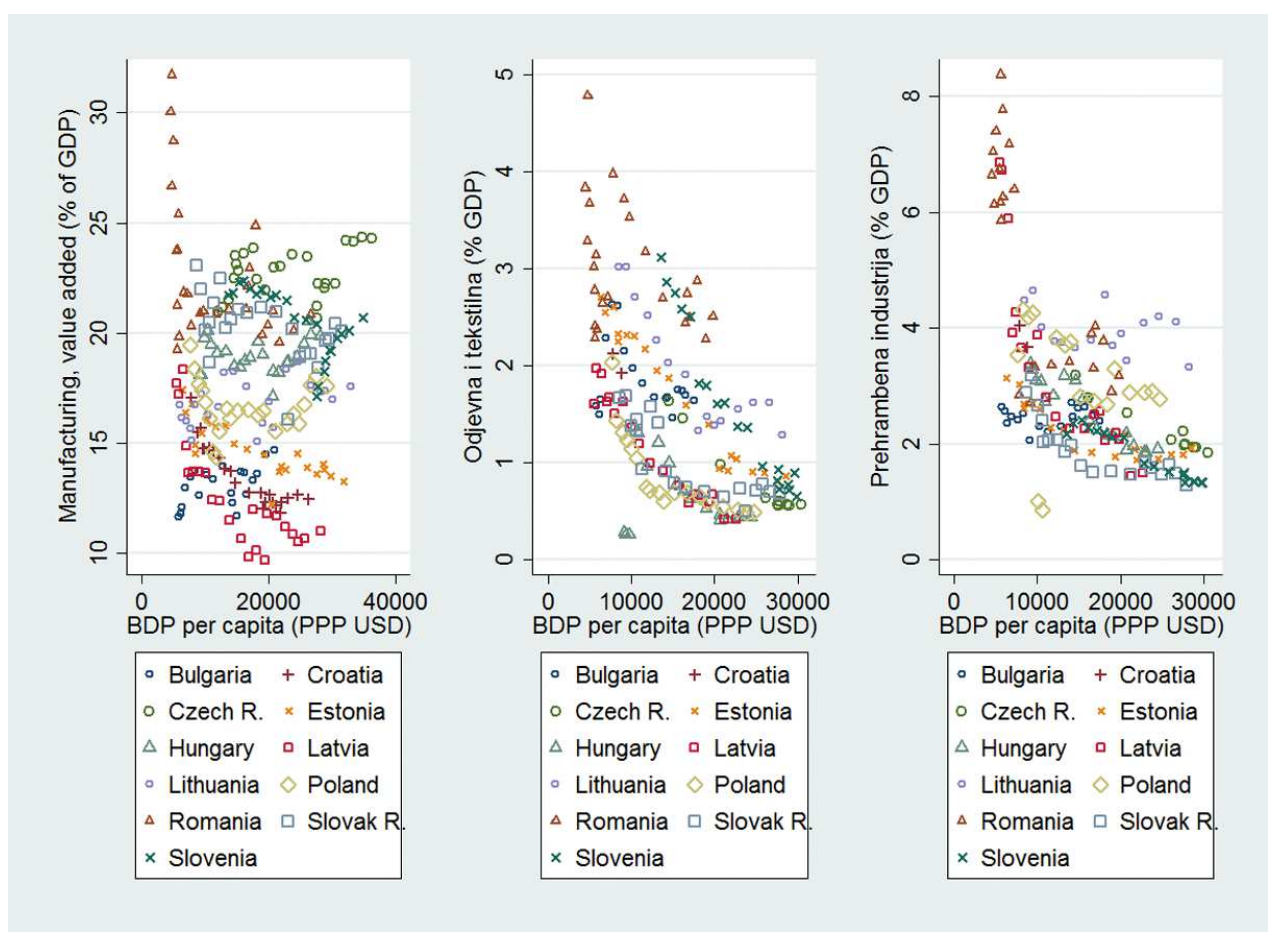

Grafikon 13: Prerađivačka industrija, odjevna i tekstilna industrija i prehrambena industrija

Izvor: WDR (2019)

Grafikon 14 prikazuje odnos razvijenosti i udjela industrije strojeva i transportne opreme (lijevo), kemijske industrije (sredina) i ostalih industrija koje nisu prikazane zasebno na grafikonima. Lijevi grafikon pokazuje da postoji grupa zemalja u kojoj je razvidna pozitivna korelacija između udjela industrija strojeva i opreme sa stupnjem razvoja. U navedenoj grupi zemalja se nalaze Češka, Slovačka, Rumunjska, Mađarska, Slovenija, Estonija i u manjoj mjeri Poljska. Na dnu grafikona su dvije preostale baltičke države, Hrvatska i Bugarska bez vidljivih znakova korelacije.

Kod kemijske industrije (sredina grafikona) postoji određeni stupanj pozitivne korelacije u nekim zemljama (Slovenija i Mađarska), ali ne i na razini cijelog uzroka. Sličan zaključak se nameće i za ostale industrije (desni grafikon). Međutim, unatoč manjku uoč- 
ljivih pozitivnih korelacija, razvidno je iz prikazanog kako su negativne korelacije prisutne samo u slučaju tekstile, odjevne i prehrambene industrije kao i udjela poljoprivrede, dok na ostalim grafikonima ne postoji jasna negativna veza.

Razvidno je dakle iz ove jednostavne grafičke analize podataka kako je teško uočiti obrazac deindustrijalizacije unutar grupe tranzicijskih zemalja koje su postale članicama EU. Opadanje udjela prehrambene, tekstile i odjevne industrije je uočljivo, ali na razini dodane vrijednosti cijele industrije kao i na razini industrije strojeva i transportne opreme, te kemijske industrije u čitavom nizu zemalja uočljivi su trendovi industrijalizacije, odnosno rasta udjela prerađivačke industrije.
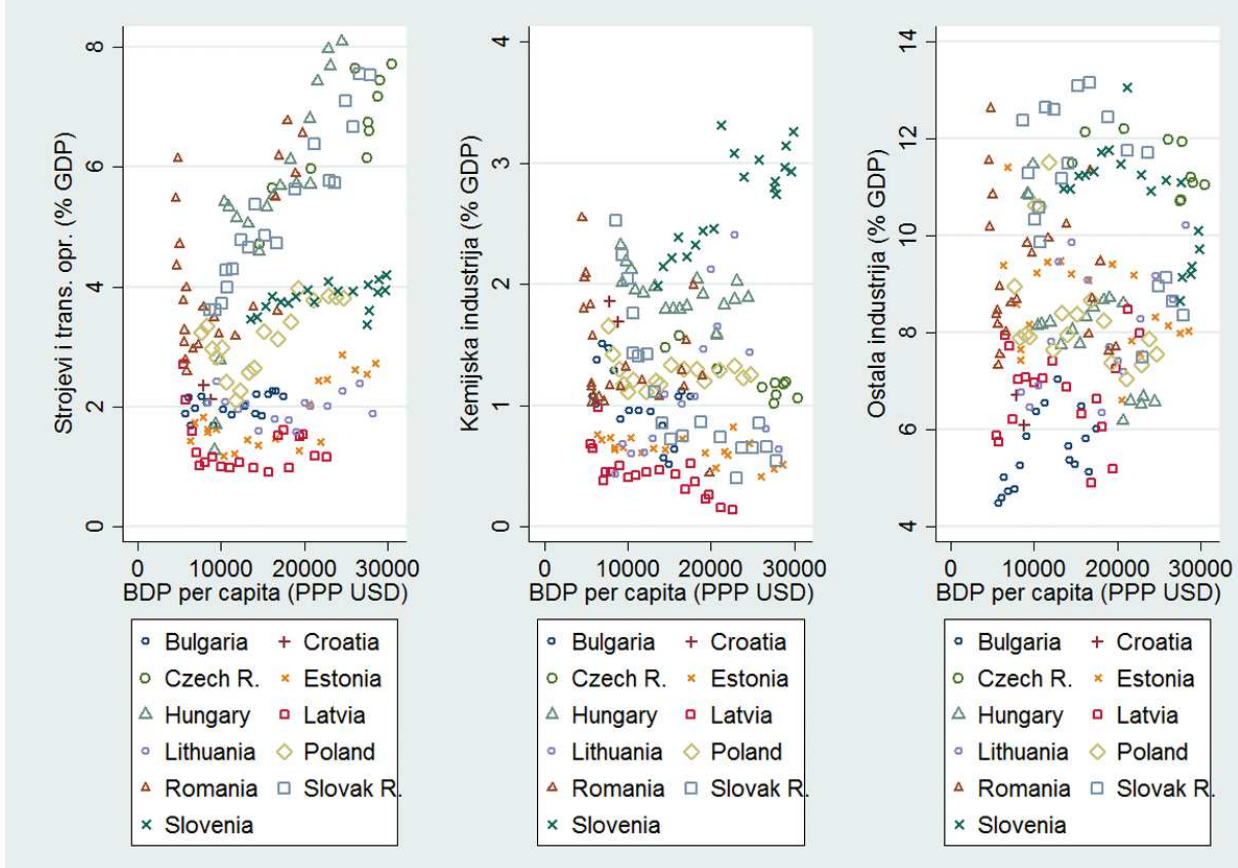

Grafikon 14: Industrija strojeva i transportne opreme, kemijska industrija i ostala industrija 


\section{EKONOMETRIJSKA ANALIZA}

Empirijska provjera svih navedenih teorija napravljena je pomoću panel modela fiksnih efekata koji kontrolira za heterogenost među zemljama i tijekom vremena (two way fixed efect model). Osnovna regresijska funkcija je opisana na slijedeći način:

$$
\Delta y_{i t}=\alpha_{i}+\mu_{t}+\beta y_{i 0}+\psi X_{i t}+\pi Z_{i t}+\epsilon_{i t}
$$

gdje je $\Delta y_{i t}$ stopa rasta (log-diferencija) BDP-a per capita izraženog nacionalnog valuti promatrane zemlje i (LCU-local currency unit). ${ }^{?}$ Fiksni efekti za zemlje su označeni kao $\alpha_{i}$, a fiksni efekti za vrijeme kao $\mu_{t}$. Inicijalna razina BDP-a per capita u tekućim PPP dolarima je $y_{i 0}$ i služi kako bi procijenili efekt konvergencije (utjecaj početne razine BDP-a na stope rasta). Vektor $X_{i t}$ se sastoji od klasičnih faktora rasta iz osnovnih verzija modela vezanih uz originalni Solow (1956) model i pristup testiranju koji su primijenili Mankiw, Romer i Weil (1992). Radi se o udjelu investicija u BDP-u (gfcf), stopi rast populacije (dypop), ljudskom kapitalu (hc) i utjecaju promjene stope zaposlenosti na BDP per capita (dyemp). ${ }^{8} \mathrm{U}$ vektoru $Z_{i t}$ kontroliramo procjenu sa različitim kombinacijama slijedećih nezavisnih varijabli: Otvorenost (open - udio zbroja uvoza i izvoza u BDP-u), stopi rasta prerađivačke industrije (dymanuf), stupnju razvoja financijskog sektora (marktcap - omjer kapitalizacije burze i BDP-a), izdvajanjima za R\&D, stopi inflacije (infl), kamatama placenim na javni dug (intpaid), apreciranosti tečaja (Aprec_tecaj), stopi rasta stupnja složenosti izvoznih proizvoda (dyeci), udjelu tehnološki složenog izvoza (hitech) i stopi rasta renti od prirodnih resurs (dynaturesrs) uključujući i primitke od turizma.

Tablica 1 prikazuje rezultate 8 procijenjenih modela. U prvih pet redova se nalaze procijenjeni koeficijenti za varijable iz vektora $X_{i t}$, a nakon toga slijede procijenjeni koeficijenti za varijable iz vektora $Z_{i t}$. Procijenjeno je osam modela sa različitim elementima vektora $Z_{i t}$. Varijable koje su bile izbačene iz svakog pojedinog modela, u kolonama nemaju unesenu vrijednost za procjenu koeficijenta i p vrijednosti. 
Tablica 1: Regresije rasta za tranzicijske zemlje u razdoblju od 1990. do 2018. godine.

\begin{tabular}{|c|c|c|c|c|c|c|c|c|}
\hline & $\begin{array}{c}\text { (1) } \\
\text { dylcu90 }\end{array}$ & $\begin{array}{c}(2) \\
\text { dylcu90 }\end{array}$ & $\begin{array}{c}(3) \\
\text { dylcu90 }\end{array}$ & $\begin{array}{c}\text { (4) } \\
\text { dylcu90 }\end{array}$ & $\begin{array}{c}\text { (5) } \\
\text { dylcu90 }\end{array}$ & $\begin{array}{c}\text { (6) } \\
\text { dylcu90 }\end{array}$ & $\begin{array}{c}(7) \\
\text { dylcu90 }\end{array}$ & $\begin{array}{c}(8) \\
\text { dylcu90 }\end{array}$ \\
\hline ylag5 & $\begin{array}{l}-4.520 * * * \\
(0.009)\end{array}$ & $\begin{array}{l}-3.925^{* * * *} \\
(0.007)\end{array}$ & $\begin{array}{l}-5.412 * * * \\
(0.000)\end{array}$ & $\begin{array}{l}-6.130 * * * \\
(0.001)\end{array}$ & $\begin{array}{l}-7.851 * * * \\
(0.000)\end{array}$ & $\begin{array}{l}-6.287 * * * \\
(0.000)\end{array}$ & $\begin{array}{l}-5.193 * * * \\
(0.000)\end{array}$ & $\begin{array}{l}-4.610 * * * \\
(0.001)\end{array}$ \\
\hline gfcf & $\begin{array}{l}0.194 * * * \\
(0.000)\end{array}$ & $\begin{array}{l}0.199 * * * \\
(0.000)\end{array}$ & $\begin{array}{l}0.178 * * * \\
(0.000)\end{array}$ & $\begin{array}{l}0.226 * * * \\
(0.000)\end{array}$ & $\begin{array}{l}0.176^{* * * *} \\
(0.000)\end{array}$ & $\begin{array}{l}0.202 * * * \\
(0.000)\end{array}$ & $\begin{array}{l}0.218^{* * * *} \\
(0.000)\end{array}$ & $\begin{array}{l}0.221 * * * \\
(0.000)\end{array}$ \\
\hline dypop & $\begin{array}{l}-0.692 * \\
(0.074)\end{array}$ & $\begin{array}{l}-0.511 \\
(0.163)\end{array}$ & $\begin{array}{l}-0.615^{*} \\
(0.098)\end{array}$ & $\begin{array}{l}-0.988 * * \\
(0.029)\end{array}$ & $\begin{array}{l}-0.715^{*} \\
(0.064)\end{array}$ & $\begin{array}{l}-0.784 * * \\
(0.039)\end{array}$ & $\begin{array}{l}-0.756 * * \\
(0.042)\end{array}$ & $\begin{array}{l}-0.652 * \\
(0.080)\end{array}$ \\
\hline hc & $\begin{array}{c}2.657 \\
(0.484) \\
\end{array}$ & $\begin{array}{c}3.909 \\
(0.237) \\
\end{array}$ & $\begin{array}{c}4.644 \\
(0.109) \\
\end{array}$ & $\begin{array}{c}8.272 * \\
(0.056) \\
\end{array}$ & $\begin{array}{c}2.145 \\
(0.454) \\
\end{array}$ & $\begin{array}{c}2.321 \\
(0.408) \\
\end{array}$ & $\begin{array}{c}4.655 \\
(0.128) \\
\end{array}$ & $\begin{array}{c}3.401 \\
(0.294) \\
\end{array}$ \\
\hline dyemp & $\begin{array}{l}0.441 * * * \\
(0.000)\end{array}$ & $\begin{array}{l}0.496 * * * \\
(0.000)\end{array}$ & $\begin{array}{l}0.490 * * * \\
(0.000)\end{array}$ & $\begin{array}{l}0.475 * * * \\
(0.000)\end{array}$ & $\begin{array}{l}0.509 * * * \\
(0.000)\end{array}$ & $\begin{array}{l}0.501 * * * \\
(0.000)\end{array}$ & $\begin{array}{l}0.451 * * * \\
(0.000)\end{array}$ & $\begin{array}{l}0.473 * * * \\
(0.000)\end{array}$ \\
\hline open & $\begin{array}{l}0.036 * * \\
(0.023)\end{array}$ & $\begin{array}{c}0.024 * \\
(0.052) \\
\end{array}$ & $\begin{array}{c}0.014 \\
(0.232) \\
\end{array}$ & $\begin{array}{c}0.016 \\
(0.299) \\
\end{array}$ & $\begin{array}{l}-0.003 \\
(0.823) \\
\end{array}$ & $\begin{array}{c}0.002 \\
(0.883) \\
\end{array}$ & $\begin{array}{c}0.010 \\
(0.432) \\
\end{array}$ & $\begin{array}{c}0.012 \\
(0.310) \\
\end{array}$ \\
\hline dymanuf & $\begin{array}{c}0.037 * \\
(0.067)\end{array}$ & $\begin{array}{l}0.072 * * * \\
(0.000)\end{array}$ & $\begin{array}{l}0.079 * * * \\
(0.000)\end{array}$ & $\begin{array}{l}0.044 * * \\
(0.042)\end{array}$ & $\begin{array}{l}0.069 * * * \\
(0.000)\end{array}$ & $\begin{array}{l}0.086^{* * * *} \\
(0.000)\end{array}$ & $\begin{array}{l}0.061 * * * \\
(0.001)\end{array}$ & $\begin{array}{l}0.070 * * * \\
(0.000)\end{array}$ \\
\hline marktcap & $\begin{array}{c}0.020 \\
(0.325) \\
\end{array}$ & & & & & & & \\
\hline $\mathrm{RnD}$ & & $\begin{array}{l}-0.541 \\
(0.512) \\
\end{array}$ & & & & & & \\
\hline infl & & & $\begin{array}{l}-0.006 * * \\
(0.030)\end{array}$ & & & & & \\
\hline intpaid & & & & $\begin{array}{c}0.224 \\
(0.180) \\
\end{array}$ & & & & \\
\hline $\begin{array}{l}\text { Aprec_ } \\
\text { tecaj }\end{array}$ & & & & & $\begin{array}{c}0.565 \\
(0.866) \\
\end{array}$ & & & \\
\hline dyeci & & & & & & $\begin{array}{c}0.002 \\
(0.279) \\
\end{array}$ & & \\
\hline hitech & & & & & & & $\begin{array}{c}0.120 \\
(0.265) \\
\end{array}$ & \\
\hline dynatresrs & & & & & & & & $\begin{array}{l}0.018 * * \\
(0.022) \\
\end{array}$ \\
\hline _cons & $\begin{array}{l}30.760 * \\
(0.098)\end{array}$ & $\begin{array}{c}20.957 \\
(0.198) \\
\end{array}$ & $\begin{array}{l}31.401 * * \\
(0.021)\end{array}$ & $\begin{array}{l}29.335 \\
(0.119) \\
\end{array}$ & $\begin{array}{l}58.014 * * * \\
(0.000)\end{array}$ & $\begin{array}{l}44.754 * * * \\
(0.000)\end{array}$ & $\begin{array}{l}30.549 * * \\
(0.035)\end{array}$ & $\begin{array}{l}27.055^{*} \\
(0.076)\end{array}$ \\
\hline $\mathrm{N}$ & 259 & 300 & 371 & 295 & 378 & 365 & 352 & 357 \\
\hline rmse & 2.447 & 2.534 & 2.818 & 2.866 & 2.954 & 2.876 & 2.758 & 2.785 \\
\hline $\mathrm{r} 2$ & 0.683 & 0.696 & 0.596 & 0.622 & 0.590 & 0.594 & 0.623 & 0.607 \\
\hline r2_a & 0.618 & 0.636 & 0.533 & 0.552 & 0.527 & 0.534 & 0.562 & 0.544 \\
\hline
\end{tabular}

Napomena: *,**, *** označavaju razinu signifikatnosti od 10, 5 i $1 \%$.

Izvor: Izračun autora

Rezultati ukazuju na činjenicu kako je utjecaj vremenskog pomaka razine razvoja $y_{i 0}$ u tablici označen kao ylag5 signifikantan u svim modelima. Navedeno implicira kako 
postoji beta konvergencija unutar uzorka. Rezultat je robustan na različite specifikacije modela, negativnog je predznaka i na razini signifikantnosti od $1 \%$. Negativan predznak implicira kako početna razina BDP-a negativno utječe na stopu rasta BDP-a tijekom idućih pet godina (početna razina je u modelu sa vremenskim pomakom od pet godina).

Slijedeća varijabla koja signifikantno na razini od $1 \%$ djeluje na stope rasta je udio investicija u BDP-u. Predznak je pozitivan u skladu sa predviđanjima Solow modela. Stopa rasta populacije (dypop) ima negativan predznak u svim modelima, ali statistička signifikantnost procjena nije robusna na različite specifikacije modela. Ljudski kapital (hc) ima pozitivan predznak, ali p vrijednosti su iznad klasičnih razina signifikantnosti. Stopa rasta zaposlenosti je robustna u svim modelima i pozitivno djeluje na stope rasta BDP-a ukazujući kako je dobar dio razlika u stopama rasta među zemljama plod šokova na tržištu rada koji su dovoljno perzistentni da djeluju na dugoročne stope rasta. Otvorenost djeluje pozitivno, ali statistička značajnost ne pokazuje da je statistički različita od nule. Stopa rasta prerađivačke industrije (dymanuf) s druge strane ulazi u set varijabli koje su robusne u skoro svim specifikacijama jednadžbe i koje u svi procijenjenih pravcima imaju pozitivna predznak.

Za ostale varijable rezultati nisu bili niti robusni niti signifikantni u većini modela. Sukladno tome pojavljuju se u jednom od osam prezentiranih modela. Važno je ovdje istaknuti da je uvrštavanje varijable za kapitaliziranost burze u kombinaciji sa otvorenošću rezultiralo signifikantnim koeficijentima za otvorenost u gotovo svim specifikacijama modela, ali je u takvim specifikacijama procijenjenih jednadžbi procjena za udio prerađivačke industrije imala nešto manji stupanj statističke pouzdanosti.

Rezultat ekonometrijske analize u biti pokazuje kako postoji nekoliko varijable koje jako dobro objašnjavaju preko 50, a u nekim slučajevima i $60 \%$ devijacija u stopama rasta između tranzicijskih zemalja tijekom tranzicijskom perioda. Navedeni rezultati u smislu procijenjenih predznaka su u većoj mjeri u skladu s Solow teorijom rasta, ali zbog malog uzroka od 259 do 357 opservacija, određene varijable su se pokazale nesignifikantnima. Izvan standardne teorije rasta, udio prerađivačke industrije se ipak pokazao pozitivnim čimbenikom rasta, isto kao i stopa rasta primitaka od prirodnih resursa. Ekonometrijska analiza je na taj način ukazala na specifičan položaj tranzicijskih zemalja s obzirom na proces (de)industrijalizacije.

Imajući u vidu kako udio investicija u BDP-u i udio zaposlenosti u radno sposobnom stanovništvu robusno determinira stopu rasta tranzicijskih zemalja, moguće je postaviti pitanje na koji način struktura navedenih faktora djeluje na stope rasta. Nažalost, podaci o strukturi investicija nisu lako dostupni, ali je moguće promatrati efekte razvoja na udio prerađivačke industrije.

Ekonometrijska analiza je napravljena pomoću slijedeće funkcije:

$$
\text { manuf }_{i t}=\alpha_{i}+\mu_{t}+\beta_{1} Y_{i t}+\beta_{2} Y_{i t}^{2}+\psi X_{i t}+\epsilon_{i t}
$$

gdje je $Y_{i t}$ PPP BDP per capita u tekućim cijenama, a $X_{i t}$ je vektor kontrolnih varijabli u kojem se naizmjenično kroz šest procjena pojavljuju izdvajanja za istraživanja i razvoj R\&D, stupanj složenosti izvoznih proizvoda ECI i precijenjenost tečaja s obzirom na Harrod-Balassa-Samuelson trend. BDP per capita je u funkciju unesen u razinama i kvadriran sa ciljem da se procijeni nelinearni utjecaj razvijenosti na prerađivačku industriju. Naime, prema teoretskim očekivanjima, rast životnog standarda na najnižim stupnjevima 
razvoja pozitivno djeluje na prerađivačku industriju, ali nakon određene razine BDP-a per capita utjecaj bi trebao postati negativan. Sukladno tome, očekuje se konkavna funkcija s procijenjenim koeficijentima $\beta_{1}>0, \beta_{2}<0$.

Tablica 1 prikazuje procjenu navedene funkcije. Kao što je vidljivo, ako je vektor kontrolnih varijabli prazan, tada je utjecaj BDP-a per capita gotovo nepostojeći. Unošenjem kontrolnih varijabli koeficijenti za BDP ostaju i dalje nesignifikantni, ali s druge strane varijable iz kontrolnog vektora su robusno pouzdane. Izdvajanja za istraživanja i razvoj imaju signifikantan i pozitivan utjecaj u sva tri modela u koje su uvršteni. Stupanj složenosti izvoznih proizvoda isto tako ima pozitivan i signifikantan koeficijent u svim modelima. Od negativnih parametara se ističe odstupanje apsolutnog realnog tečaja mjerenog PPP indeksom od HBS trenda. Koeficijent je signifikantan i negativan i implicira činjenicu kako je opća razina cijena relativno važna u cjenovnoj konkurentnosti prerađivačke industrije, dok su složenost proizvoda i istraživanja i razvoj dobar indikator necjenovne konkurentnosti zemlje.

Tablica 2: Udio prerađivačke industrije kao funkcija čimbenika razvoja i seta kontrolnih varijabli

\begin{tabular}{|c|c|c|c|c|c|c|}
\hline & $\begin{array}{c}\text { (1) } \\
\text { manuf }\end{array}$ & $\begin{array}{c}(2) \\
\text { manuf }\end{array}$ & $\begin{array}{c}\text { (3) } \\
\text { manuf }\end{array}$ & $\begin{array}{c}\text { (4) } \\
\text { manuf }\end{array}$ & $\begin{array}{c}(5) \\
\text { manuf }\end{array}$ & $\begin{array}{c}\text { (6) } \\
\text { manuf }\end{array}$ \\
\hline cGDPpcPPP & $\begin{array}{l}-0.000 \\
(0.442) \\
\end{array}$ & $\begin{array}{c}-0.000 \\
(0.480) \\
\end{array}$ & $\begin{array}{l}-0.000 \\
(0.846) \\
\end{array}$ & $\begin{array}{l}-0.000 \\
(0.801) \\
\end{array}$ & $\begin{array}{c}-0.000 \\
(0.278) \\
\end{array}$ & $\begin{array}{c}0.000 \\
(0.920) \\
\end{array}$ \\
\hline cGDPsq & $\begin{array}{c}0.000^{*} \\
(0.075) \\
\end{array}$ & $\begin{array}{c}0.000 \\
(0.313) \\
\end{array}$ & $\begin{array}{c}0.000 \\
(0.187) \\
\end{array}$ & $\begin{array}{c}0.000 \\
(0.420) \\
\end{array}$ & $\begin{array}{c}0.000^{*} \\
(0.070)\end{array}$ & $\begin{array}{c}0.000 \\
(0.576)\end{array}$ \\
\hline Aprec_tecaj & & $\begin{array}{l}-5.889 * * \\
(0.014)\end{array}$ & & $\begin{array}{l}-3.516 * * \\
(0.038)\end{array}$ & & $\begin{array}{l}-3.103 * \\
(0.085)\end{array}$ \\
\hline $\mathrm{RnD}$ & & & $\begin{array}{l}1.684 * * * \\
(0.000)\end{array}$ & $\begin{array}{l}1.708^{* * *} \\
(0.000)\end{array}$ & & $\begin{array}{c}1.297 * * \\
(0.011) \\
\end{array}$ \\
\hline ECI & & & & & $\begin{array}{l}1.839 * * * \\
(0.000)\end{array}$ & $\begin{array}{c}0.759 * \\
(0.075) \\
\end{array}$ \\
\hline _cons & $\begin{array}{l}21.805^{* * * *} \\
(0.000)\end{array}$ & $\begin{array}{l}21.941 * * * \\
(0.000)\end{array}$ & $\begin{array}{l}17.408 * * * \\
(0.000)\end{array}$ & $\begin{array}{l}17.579 * * * \\
(0.000)\end{array}$ & $\begin{array}{l}18.638 * * * \\
(0.000)\end{array}$ & $\begin{array}{l}17.546^{* * *} \\
(0.000)\end{array}$ \\
\hline $\mathrm{N}$ & 650 & 650 & 430 & 430 & 531 & 401 \\
\hline rmse & 3.064 & 3.051 & 1.649 & 1.641 & 2.317 & 1.637 \\
\hline $\mathrm{r} 2$ & 0.329 & 0.336 & 0.355 & 0.362 & 0.245 & 0.358 \\
\hline r2_a & 0.263 & 0.270 & 0.268 & 0.274 & 0.169 & 0.269 \\
\hline
\end{tabular}

Napomena: *,**, *** označavaju razinu signifikatnosti od 10, 5 i $1 \%$.

Izvor: Izračun autora

Koeficijenti za kvadrirani BDP (cGDPsq) su kao što se vidi samo u dva modela signifikantni na 10\%, dok su koeficijenti za linearni BDP u svim modelima nesignifikantni. Međutim, čak i procijenjene vrijednosti navedenih koeficijenata ne odgovaraju niti približno predznacima koje bi očekivali na temelju teoretskih predviđanja.

Grafikon 15 prikazuje simulirani odnos između BDP-a per capita i udjela prerađivačke industrije na temelju procijenjenih koeficijenata $\beta_{1}, \beta_{2}$ iz modela 1-6. Zanimljivo je kako je koeficijent $\beta_{1}$ matematički (ne i statistički) u svim procjenama manji od nule što ukazuje na negativnu vezu na niskim stupnjevima razvoja, dok je koeficijent $\beta_{2}$ pozitivan, 
a u dva slučaja čak i signifikantno različit od nule. Navedeno ukazuje na konveksnost odnosa, odnosno činjenicu kako će zbog toga nakon neke razine razvoja, udio prerađivačke industrije početi rasti.

1

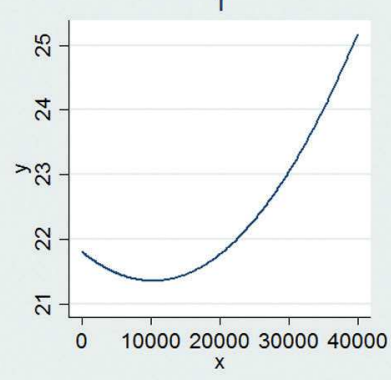

4

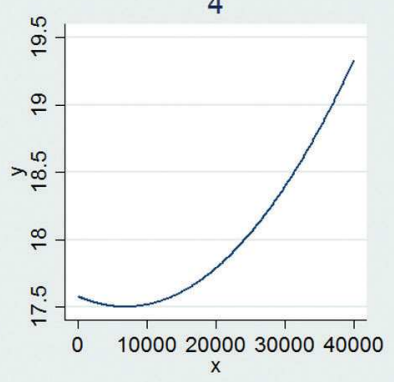

2

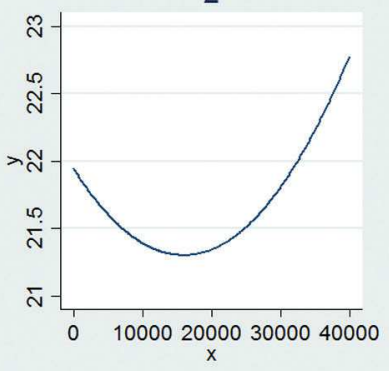

5

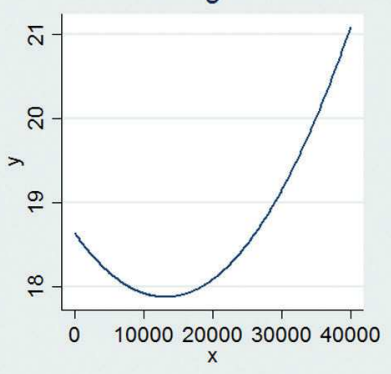

3

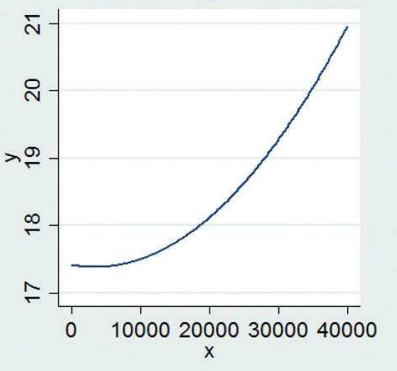

6

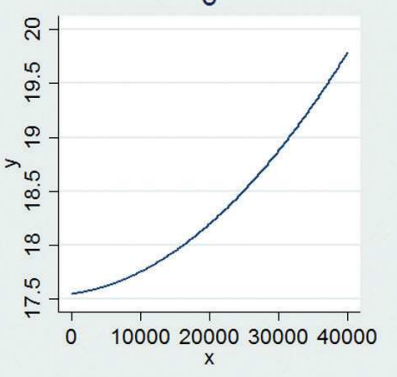

Grafikon 15: Simulirani odnos između BDP-a per capita i udjela prerađivačke industrije na temelju procijenjenih koeficijenata $\beta_{1}, \beta_{2}$ (brojevi označavaju brojeve modela iz ekonometrijske procjene - Tablica 2)

Izvor: Izračun autora

\section{ZAKLJUČAK}

U radu je napravljena vizualna i ekonometrijska analiza odabranih faktora rasta i strukture tranzicijskih gospodarstava. Iako je bivarijantna grafička analiza podataka ukazala kako su gotovo svi odabrani čimbenici korelirani sa stopama rasta, rezultati multivarijantnog ekonometrijskog testa su ukazali kako varijacije u stopama rasta najbolje objašnjava udio investicija u BDP-u, udio zaposlenosti u radno sposobnom stanovništvu, udio prerađivačke industrije i razina BDP-a per capita na kojoj se zemlja nalazi (konvergencijski faktor). Identificiran je i negativan efekt stope rasta populacije, ali je statistička pouzdanost bila robusna u manjoj mjeri, kao i kod otvorenosti gospodarstva. Kod ljudskog kapitala procijenjen je pozitivan koeficijent, ali statistički nesignifikantan.

$\mathrm{U}$ analizi promjena u strukturi gospodarstva, rezultati su pokazali da stupanj razvijenosti, odnosno BDP per capita ne djeluje statistički signifikantno na udio prerađivačke 
industrije, kako u linearnom, tako i u nelinearnom modelu. Povrh toga, analiza je pokazala kako je udio prerađivačke industrije osjetljiv na stupanj složenosti industrijskih proizvoda, kako ulaganja u istraživanje i razvoj povećavaju udio prerađivačke industrije te kako precijenjenost apsolutnog realnog tečaja mjerenog PPP indeksom djeluje negativno na udio prerađivačke industrije u BDP-u.

Ključne specifičnosti tranzicijskih zemalja po pitanju klasičnih faktora rasta prvenstveno proizlaze iz varijabli koje opisuju tržište rada. Osnovni model rasta (Solow 1956), a i brojni udžbenički izvodi navedenog modela pretpostavljaju da je u dugom roku stopa zaposlenosti, a i stopa participacije i stopa ovisnosti u biti fiksna. Sukladno tome teoretska analiza se bazira na akumulaciji kapitala po efektivnom radniku. Analiza u ovome radu prvenstveno ukazuje da neki šokovi svojstveni tranzicijskim zemljama mogu imati dugoročne posljedice na tržište rada i upravo trajne promjene stope zaposlenosti mogu objasniti velike razlike između uspješnih i neuspješnih tranzicijskih zemalja.

Povrh toga, ključna razlika u odnosu na Hrvatsku je činjenica kako su se deindustrijalizacijski trendovi u tranzicijskim zemljama odvijali u suprotnom smjeru u svim zemljama koje imaju usporedivu razvojnu razinu kao i Hrvatska. U pravilu je upravo stopa rasta određenih grana industrijske proizvodnje bila jedan od važnih faktora rasta u tranzicijskim zemljama.

Iz navedenih rezultata se jasno iščitavaju razlozi zaostajanja pojedinih zemalja u tranzicijskom procesu. Povećanjem investicija, stope zaposlenosti ili udjela prerađivačke industrije moguće je objasniti dobar dio relativnog zaostatka zemalja u tranziciji. Idemo li korak dalje i analiziramo strukturu gospodarstava očigledno je kako proces kretanja udjela prerađivačke industrije prati stohastički proces i nije nužno niti pozitivno niti negativno koreliran sa stupnjem razvijenosti. Rezultati ukazuju kako se sa ulaganjima u složenost proizvoda i/ili R\&D može održavati udio prerađivačke industrije i na višim stupnjevima razvoja.

Ograničenja ovoga istraživanja su brojna. Prvo, procjenitelj fiksnih efekata je pristran na kratkim uzrocima. Drugo, kako su Durlauf, Johnson i Temple (2004) pokazali, postoji čitav niz funkcijskih oblika, kombinacija nezavisnih varijabli i strategija procjene koje mogu rezultirati promjenom rezultata kod koeficijenata koji nisu robusni u procjeni. Isto tako, kao što je rečeno postoje brojne druge teorije za koje nisu prikupljeni podaci i koje nisu testirane s obzirom na obuhvat jednoga rada. Od 43 zasebne teorije rasta, mi smo se ovdje koncentrirali na makroekonomske čimbenike iz sfere demografije, fiskalne i monetarne politike te međunarodne ekonomike. Dobar dio institucionalnog pristupa, kao i dobar dio aproksimatora iz testiranih teorija je apstrahiran zbog skučenosti formata rada.

$\mathrm{U}$ metodološkom smislu procjene panela fiksnih efekata ne kontroliraju za problem feedbacka i međusekcijske ovisnosti, dok je procjenitelj za snagu konvergencije ujedno i svojevrsni dinamički element procjene. Isto tako funkcijski oblik procjene je teoretski upitan. Iako je prilikom procjene modela testiran nelinearni oblik utjecaja početne razine BDP-a na stope rasta, a u sektorskoj analizi testirana nelinearnost modela, mogućnost postojanja više režima između čimbenika rasta i stopa rasta nije isključena. Stoga ostaje je moguće kako bi veći broj dostupnih opservacija potencijalno rezultirao potvrdom threshold modela kao adekvatnog okvira za procjenu. 


\section{REFERENCE}

1. Acemoglu, D., S. Johnson, and J. Robinson, (2001), "The Colonial Origins of Comparative Development: An Empirical Investigation,” American Economic Review, 91, 5, 1369-1401

2. Acemoglu, D., S. Johnson and J. Robinson, (2002), "Reversal of Fortune: Geography and Institutions in the Making of the Modern World Income Distribution," Quarterly Journal of Economics, 117, 4, 1231-1294.

3. Blomstrom, M., R. Lipsey, and M. Zejan, (1996), "Is Fixed Investment the Key to Growth?," Quarterly Journal of Economics, February, 111, 1, 269-276.

4. Dollar, D., (1992), "Outward-Oriented Developing Economies Really Do Grow More Rapidly: Evidence from 95 LDCs, 1976-85," Economic Development and Cultural Change, 40, 523-544.

5. Durlauf, S.N. \& Johnson, P.A. \& Temple, J.R.W., (2004), "Growth econometrics," Working papers 18, Wisconsin Madison - Social Systems.

6. Feenstra, Robert C., Robert Inklaar and Marcel P. Timmer (2015), "The Next Generation of the Penn World Table" American Economic Review, 105(10), 3150-3182, available for download at www.ggdc.net/pwt

7. Frankel, J. and D. Romer, (1996), "Trade and Growth: An Empirical Investigation," National Bureau of Economic Research Working Paper no 5476.

8. Levine, R. and D. Renelt, (1992), "A Sensitivity Analysis of Cross-Country Growth Regressions," American Economic Review, 82, 4, 942-63.

9. Levine, R. and S. Zervos, (1993), "What We Have Learned About Policy and Growth from Cross-Country Regressions" American Economic Review Papers and Proceedings, 83, 426-430.

10. Mankiw, N. G., D. Romer, and D. Weil, (1992), "A Contribution to the Empirics of Economic Growth,” Quarterly Journal of Economics, 107, 2, 407-37.

11. Nuxoll, D. A., (1994), "Differences in Relative Prices and International Differences in Growth Rates," American Economic Review, American Economic Association, vol. 84(5), 1423-1436.

12. Obadić, A. (2003), "Industrijska politika", (Urednik: Družić, I.), Hrvatski gospodarski razvoj, Politička kultura

13. Kovačević, Z., Penava, M. i Sekur, T., (2016), "Gospodarsko značenje industrije", (Urednik: Tica, J. i Obadić, A.), Gospodarstvo Hrvatske

14. Reinhart, Carmen M., and Kenneth S. Rogoff. 2010. "Growth in a Time of Debt." American Economic Review, 100 (2): 573-78.

15. Romer, P. (1990), "Endogenous Technological Change”, Journal of Political Economy, 98(5), 71-102.

16. Sala-i-Martin, X., (1997a), "I Just Ran 4 Million Regressions," National Bureau of Economic Research Working Paper no. 6252.

17. Sala-i-Martin, X., (1997b) "I Just Ran 2 Million Regressions." American Economic Review, 87, 178-83. 
18. Solow, R., (1956), "A Contribution to the Theory of Economic Growth," Quarterly Journal of Economics, 70, 65-94.

19. Solow, R., (1994), "Perspectives on Growth Theory," Journal of Economic Perspectives, $8,45-54$.

20. WDR, (2019), "World Developments Report”, World Bank 